\title{
Use of thermal modeling to assess the tectono-metamorphic history of the Luge and Sanabria gneiss domes, Northwest Iberia
}

\author{
JAMES E. ALCOCK ${ }^{1}$, José R. MARTÍNEZ CATALÁN ${ }^{2}$, RiCARdo ARENAS ${ }^{3}$ and ALEJANDRo DÍEZ MONTES ${ }^{4}$
}

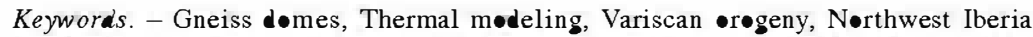

Abstract. - The Lugo and Sanabria domes in Northwest Iberia have well constrained metamorphic and structural histories. Both occur in the Iberian autochthon and resulte from late-Variscan extensional collapse following crustal thickening relate to the Variscan collision. The two domes developed beneath large thrust sheets, are cored by sillimanite-orthoclase anatectic gneiss, preserve evidence of a steep thermal gradient $\left(\approx 1{ }^{\bullet} \mathrm{C} \mathrm{MPa}^{-1}\right)$, and exhibit a distinct decrease in metamorphic grade to the east in the direction of nappe movement. Geochronological evidence indicates that the lower crust melted within $\approx 30 \mathrm{Ma}$ of initial crustal thickening and that dome formation occurre within $50 \mathrm{Ma}$.

The histories of the two domes are considered as the basis for one-dimensional finite-difference models of thermal response to changes in crustal thickness. Results from thermal models suggest that thickening was limited to the crust, provide a numeric explanation for timing and nature of granite magmatism, and indicate that high-temperature metamorphism and crustal anatexis may result directly from thermal relaxation, eliminating the nee for significant mantle thermal contribution. Also, the models show that small differences in thickness of large, wedge-shaped thrust sheets can explain distinct P-T paths experienced by different limbs of the domes.
\end{abstract}

\section{Emploi des modèles thermiques pour évaluer l'histoire tectono-métamorphique des dômes gneissiques de Lugo et Sanabria, Nord-Ouest de l'Ibérie}

\begin{abstract}
Mots-clés. - Dômes gneissiques, Mødèles thermiques, Orøgenèse varisque, N•rd-Ouest de l’Ibérie
Résumé. - L'évolution métamorphique et structurale des dômes de Lugo et Sanabria, dans le Nord-Ouest de l'Ibérie, sont bien connues. Les deux se sont formées dans l'autochtone du Massif ibérique en réponse à l'effondrement gravitaire de la chaîne varisque. Les deux dômes se sont dévelopés au-dessous de grandes nappes de chevauchement, leur coeur étant occupé par des gneiss anatectiques à sillimanite-orthose, préservant des évidences d'un gradient métamorphique assez fort $\left(\approx 1^{\bullet} \mathrm{C} \mathrm{MPa}^{-1}\right)$ et sont caractérisés par une diminution des conditions métamorphiques vers l'est, dans la direction du mouvement des nappes. Les données géochronologiques indiquent que la fusion partielle commença 30 millions d'années et la formation des dômes 50 millions d'années après le début de l'épaississement crustal.

Les histoires P-T des deux dômes sont choisies pour étudier la réponse thermique aux variations d'épaisseur crustale en utilisant la modélisation thermique par la méthode des différences finies en une dimension. Les résultats indiquent que l'épaississement a été limité à la croûte continentale, fournissant une explication numérique pour l'âge et la nature du magmatisme granitique et suggérant que le métamorphisme de haute température et l'anatexie crustale peuvent être la conséquence de la relaxation thermique, sans nécessairement invoquer une contribution significative d'une source mantélique. De plus, les modèles montrent que de petites différences dans l'épaisseur des nappes de chevauchement expliquent les différences de trajectoires P-T suivies par les deux flancs des dômes.
\end{abstract}

\section{INTRODUCTION}

England and Thompson [1984], Thompson and England [1984], and Peacock [1989] showed how to model the pressure-temperature-time (P-T-t) paths of regional metamorphism in regions of thickened continental crust. Their models place the physical conditions undergone by rocks initially at different depths in a temporal frame, permit a better understanding of the orogenic processes involved, and explain very elegantly the succession of metamorphic facies and granite generation [England and Thompson, 1986]. Further development of P-T-t modeling covers special cases in orogenic belts [Davy and Gillet, 1986; Thompson and Ridley, 1987], and the subduction and obduction of oceanic lithosphere [Peacock, 1990, 1991; Jamieson, 1986].

The results of general thermal modeling have been widely applied in regional and local studies to interpret tectono-metamorphic histories deduced from mineral assemblages of

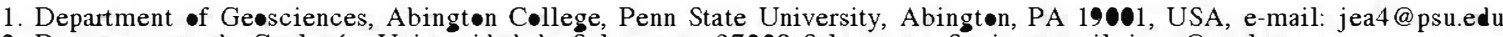

2. Departament• de Geøløgía, Universidad de Salamanca, 37008 Salamanca, Spain, e-mail: jrmc@usal.es

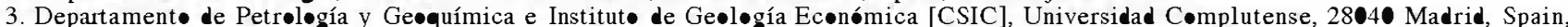
e-mail: rarenas@ge

4. Institut• Geølógic• y Miner• de España, Azafranal 48, 37001 Salamanca, Spain, e-mail: al.diez@igme.es

Manuscrit dép•sé le 22 janvier 2008 ; accepté après révisiøn le 23 mai 2008 
metamorphic rocks and their chemical equilibrium [Spear, 1989]. In most instances, the geologists built P-T paths (or P-T-t, P-T-d, P-T-t-d, where $t$ stands for time and $\mathbf{d}$ for $\mathbf{d e}-$ formation) from field and laboratory data, and use them to infer aspects of the processes undergone by metamorphic rocks, such as geotectonic settings, amount of thickening and thinning, burial and exhumation rates, and the importance of tectonic versus erosional denudation. Such an approach has been used in Northwest Iberia for the interpretation of exotic, allochthonous terranes [Gil Ibarguchi and Arenas, 1990; Arenas, 1991; Arenas et al., 1995, 1997; Martínez Catalán et al., 1996; Abati et al., 2003] and also to decipher the evolution of the Iberian autochthon at extensional gneiss domes [Escuder Viruete $e t$ al., 1994, 1997, 2000; Arenas and Martínez Catalán, 2003].

Here, we propose a quite different use of thermal modeling: assessing what is known about the evolution of particular structures or regions. Comparing the available structural and petrologic data with model results may help to constrain the deduced tectono-metamorphic history either showing that it is reasonable or by identifying potential inconsistencies and errors. Furthermore, comparison between field results and models may provide hints to a wider understanding of the orogenic process, in particular, concerning the involvement of the deep parts of the crust and lithosphere that cannot be directly observed.

Gneiss domes are common structures in orogenic belts. They are formed during the late orogenic stages associated with extensional processes, and the involved rocks have registered the whole thermobaric history of the belt at a wide range of depths. Thermomechanical modeling has been applied to gneiss domes of different types to understand their evolution by Burg et al. [2004], Fayon et al. [2004], Gerya et al. [2004] and Tirel et al. [2004].

This work carries out numerical models on the thermobaric evolution of two such structures, the Lugo and Sanabria gneiss domes, and compares our geological knowledge with the model results obtained. Both structures are geologically well known and representative of the Variscan thickening and subsequent extension by gravitational collapse of the orogen. The initial and boundary conditions are derived from the regional geological background, which includes the geometry and nature of the main tectonic, metamorphic and magmatic events and their approximate age. For the physical parameters of rocks, standard values given in the geological literature are used, adapted to the particular case. Available estimates of the P-T paths deduced from the mineral associations are a very important constraint for model evaluation, but not form part of the boundary conditions. Instead, the known P-T evolution is the reference to which the results of thermal modeling are compared, providing a test for the validity of the assumptions concerning the orogenic evolution and/or the physical parameters and the numerical models. Published isotopic ages of granitoids are also used to test the accuracy of the models.

Modeling is used here to shed light on regional aspects of the orogenic evolution such as the age of the main deformation events, the amount of crustal thickening and thinning undergone, the strain rates, and to evaluate existing $\mathrm{P}-\mathrm{T} \pm \mathrm{t} \pm \mathbf{d}$ paths inferred from structure, geochronology and mineral petrogenesis. Model results partly conform to prior inferences; however, there are a few areas in which the results require re-examination of prior interpretations, such as mantle delamination occurring late in the orogenic cycle, and the inferre isobaric P-T paths of rocks in the footwall to major thrust sheets. Model data also suggest that thickening of the lithosphere was limited to the crust, a result that could not be directly inferred from existing geological data.

\section{GEOLOGICAL SETTING}

The Northwest Iberian Variscan basement consists of lowto high-grade metamorphic rocks and granitoids. Internal areas occur in the west or southwest, whereas the external zones crop out to the northeast. A distinction can be established between the Iberian autochthon and the allochthonous complexes (fig. 1), both being separated by the lower allochthon, a thrust sheet, several kilometres thick. Recent reviews on the evolution of Northwest Iberia are presented in Arenas et al. [2007] and Martínez Catalán et al. [2007].

The autochthon developed in a marginal part of northern Gondwana characterized by Archean and Paleoproterozoic basement. It underwent intensive Cadomian reworking during Neoproterozoic arc-continent collision [Montero et $\boldsymbol{a l}$., 2007], and subsequent Cambro-Ordovician rifting related to peri-Gondwanan terrane dispersion. Both events produced abundant granitoids and felsic volcanics, presently transformed into orthogneisses. The succession includes a thick Neoproterozoic terrigenous sequence (Vilalba Series), a complete and thick Cambrian to Early Devonian shallow-water marine sequence, and a few synorogenic Carboniferous deposits. Slates and schists are the most common rocks, but sandstones, quartzites and carbonates are also abundant in the Paleozoic sequence, which is typical of a passive continental margin. The most continuous Paleozoic quartzite and carbonate formations have been drawn in the cross-sections of figure 2 to show the structure. Also important is an Early Ordovician volcanogenic unit several kilometers thick known as the Ollo de Sapo Fm, of rhyolitic and dacitic composition. Granitic orthogneisses of roughly the same age and geochemically related were intruded in the underlying successions [Díez Montes, 2007].

The lower allochthon (fig. 1) consists of Early Ordovician to Devonian metasediments, volcanic, and plutonic rocks, which can be correlated to those of the autochthon, from which they are separated by a large, low-dipping thrust fault [Farias et al., 1987]. The allochthonous complexes are the remnant of a thick nappe pile preserved in the core of late Variscan synforms. They consist of a stack of units separated by thrusts faults and extensional detachments, which represent accreted, exotic terranes. These include pieces of rifted continental margins, volcanic arcs and oceanic lithosphere, many of them affected by subduction-related high-pressure metamorphism [Arenas et al., 2007; Martínez Catalán et al., 2007, and references therein].

The Lugo and Sanabria domes [Martínez et al., 1988] form part of the autochthon, but their metamorphic and structural evolution was influenced by the emplacement of the allochthonous complexes. The evolution of the latter is too complex and beyond the scope to be dealt with here, but that of the domes is important for the models, and is described in the next sections. 


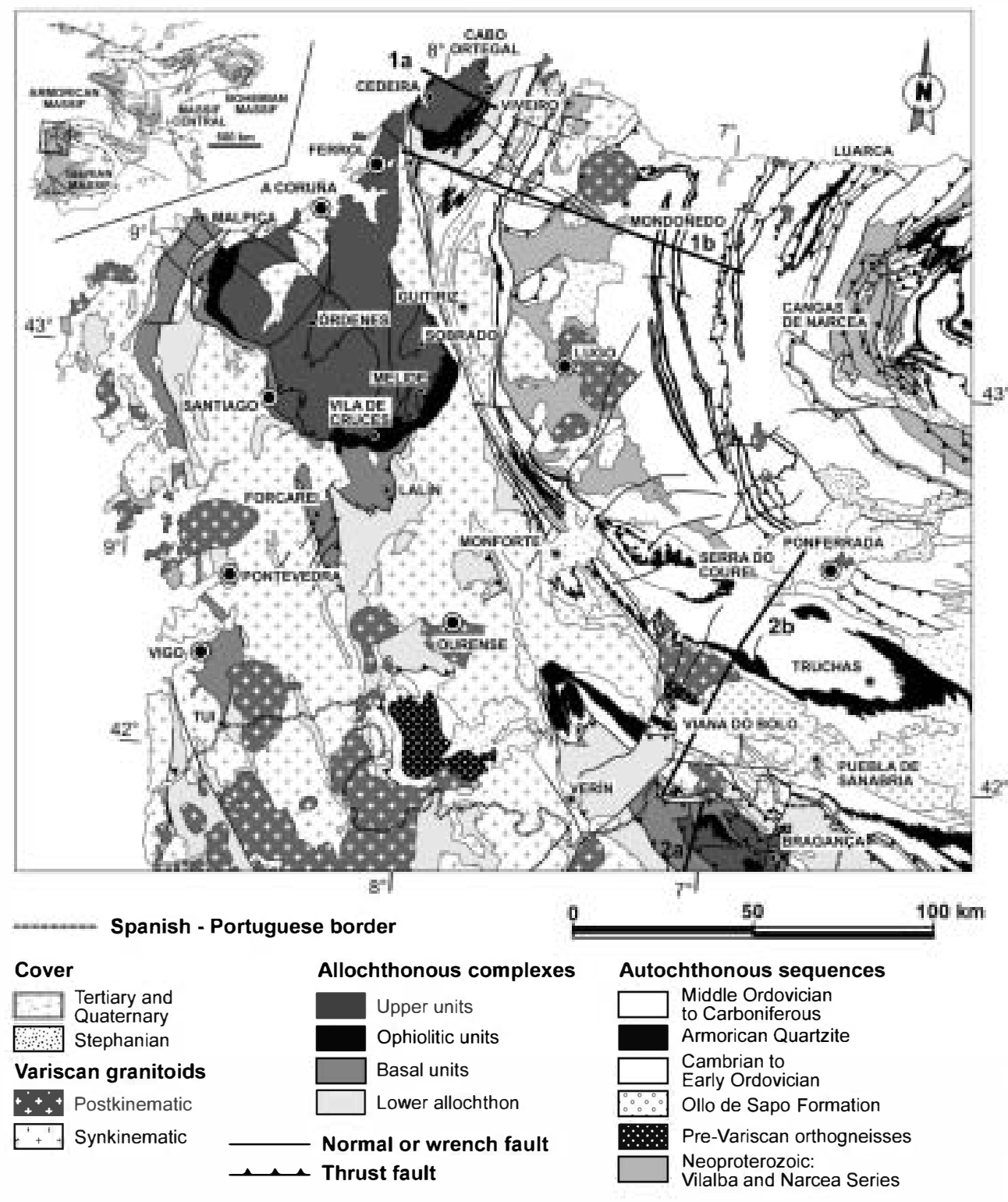

FIG. 1. - Geologic sketch of Northwest Iberia. The location of cross sections in figure 2 is indicated.

FIG. 1. - Carte zéologique du Nord-Ouest de l'Ibérie avec indication des coupes géologiques de la figure 2.

\section{STRUCTURE AND EVOLUTION OF THE LUGO AND SANABRIA DOMES}

The Lugo dome [Capdevila, 1969] is a wide N-S antiformal structure, $140 \mathrm{~km}$ long and $35 \mathrm{~km}$ wide structure going from Viveiro, on the Cantabrian coast, to the Serra do Courel (fig. 1). Its core is occupied by the deep parts of the Mondoñedo nappe [Matte, 1968] and its relative autochthon. The nappe is a set of kilometric-scale recumbent folds floored by a thrust fault [Bastida et al., 1986], below which the autochthon crops out in the Xistral tectonic window (fig. 2). The Sanabria dome [Díez Montes, 2007] is also an open antiform, $50 \mathrm{~km}$ long and $20 \mathrm{~km}$ wide, elongated in the NW-SE direction, and situated to the south of the Lugo dome, between Viana do Bolo and Sanabria (fig. 1). Its core is occupied by the Ollo de Sapo anticlinorium (fig. 2), characterize by relatively small recumbent folds, and where no thrust faults have been identified, although the Mondoñedo nappe crops out to the northeast and its basal thrust probably continues down below the dome.
The two antiforms are characterized by high-temperature Variscan metamorphism, reaching the sillimaniteorthoclase zone, and by a pervasive schistosity related to extensional tectonics. Partial melting is evident in migmatites develope at their cores, and in the voluminous Variscan granitoids intruded. Both antiforms are flanked by synforms. To the east, the Bretona and Truchas synforms are very open structures cored by low-grade Paleozoic metasediments. To the west, two large normal faults, the Viveiro and Chandoiro faults (fig. 2) separate the antiforms from two open synforms that host the remnants of the allochthonous nappe pile forming the complexes of Cabo Ortegal and Bragança (figs. 1, 2).

On kinematic grounds, the Lugo and Sanabria antiforms do not seem to have developed in the footwall to extensional detachments by elastic rebound of the lithosphere. For the Lugo antiform to be interpreted in that way, the lower extensional shear zone and detachment should have a top-to-west kinematics, whereas it is just the opposite (fig. 2). For the Sanabria antiform, the stretching lineation 
and shear sense associated with exhumation is nearly parallel to its axis, instead of being perpendicular. Both antiforms are interpreted as extensional gneiss domes in the sense of Burg et al. [1994] and Tirel et al. [2004], as they have granitic and migmatitic cores developed after Variscan crustal thickening, a strong subhorizontal fabric developed during exhumation, and are bounded by extensional detachments and normal faults. Their structural evolution includes shortening and crustal thickening, related to plate convergence, as well as extension and crustal thinning linked to gravitational collapse of the weakened orogenic crust. Several generations of structures permit the individualization of three contractional $(\mathrm{C} 1, \mathrm{C} 2$ and $\mathrm{C} 3)$ and two extensional (E1 and E2) deformation events, although most of them are diachronous and may overlap in time. These structures and events are described briefly here, whereas more detailed descriptions are available in Bastida et al. [1986], Arenas and Martínez Catalán [2003], Martínez Catalán et al. [2003, 2004], and Díez Montes [2007]. Published geophysical data and interpretations include seismic profiling [Córdoba et al., 1987; Ayarza et al., 19981, and gravity and magnetic modeling [Ayarza and Martínez Catalán, 2007].

\section{Recumbent folding (C1)}

The first deformation event produced a regular train of folds, inclined to recumbent, with northeast vergence. Very large folds occur in the Mondoñedo nappe (fig. 2), where the largest overturned limb reaches $15-30 \mathrm{~km}$ due to post-folding horizontal shearing related in part to thrusting and in part to late orogenic extension. To the west and south, recumbent folds are common in low-grade areas, but they are smaller, their reverse limbs rarely attaining $5 \mathrm{~km}$. A low-grade slaty cleavage or foliation $\left(S_{1}\right)$ developed pervasively in the slates and in the Ollo de Sapo Fm. The associated stretching lineation, with along-dip attitude, indicates that the deformational flow was perpendicular to the orogenic trend, so that significant strike-slip components seem not to be associated to early folding.

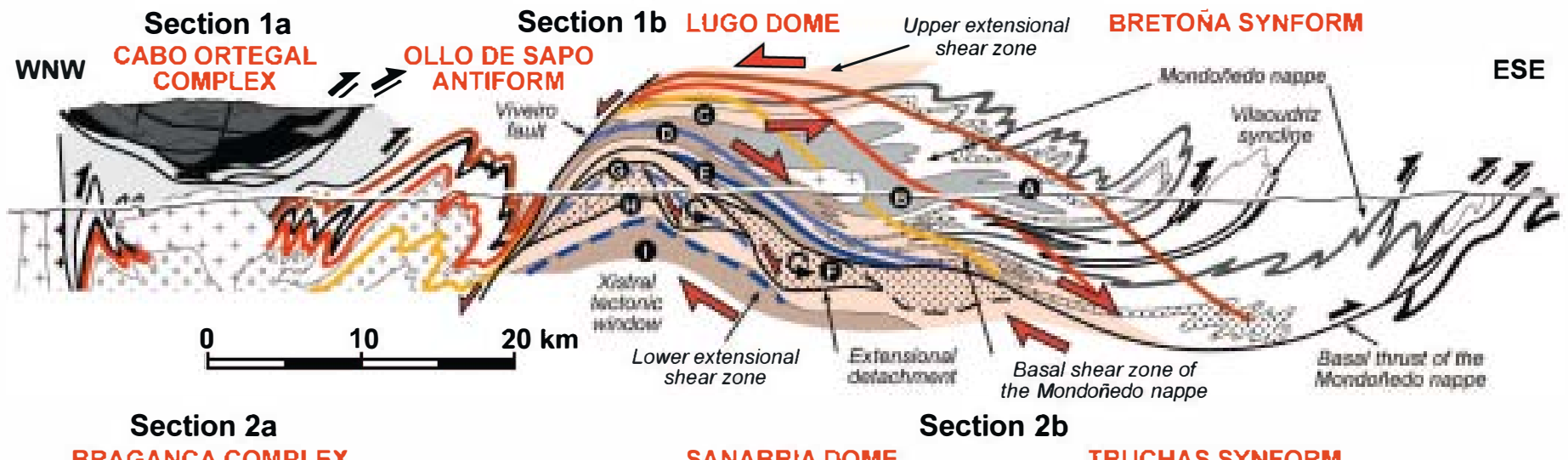

\section{BRAGANÇA COMPLEX}

ssw

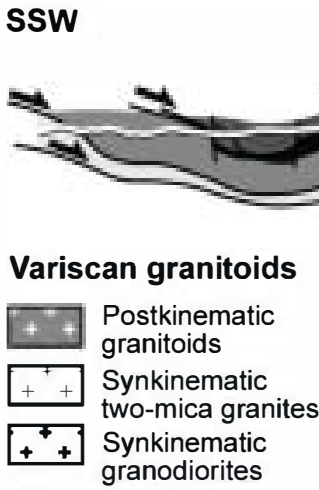

Allochthonous complexes

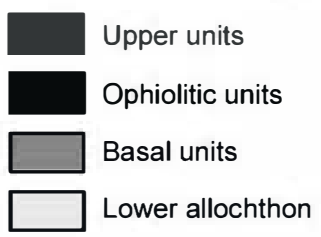

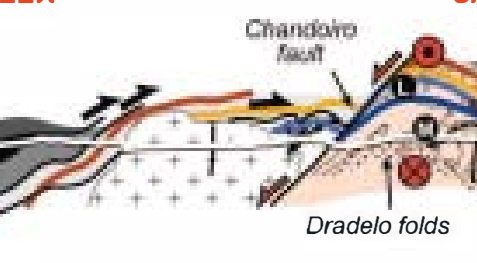

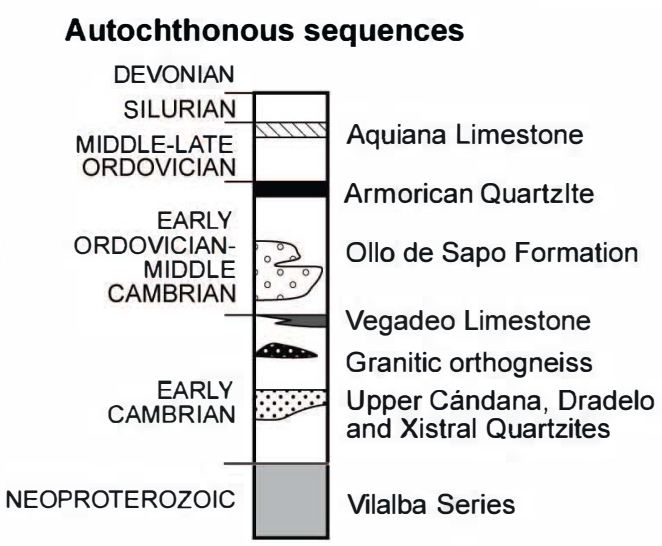

\section{Ductile shear zones}

$\square$ Extensional shear zones in the Lugo and Sanabria domes

\section{Isograds}

Ollo de Sapo antiform and Mondoñedo nappe

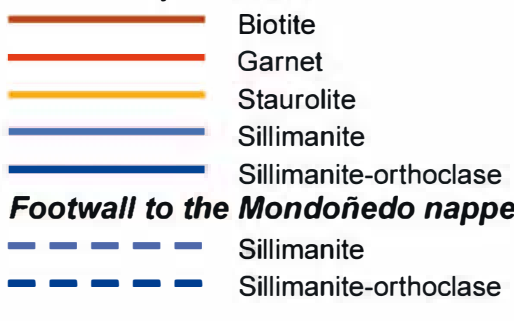

FIG. 2. - Geologic sections across the Lugo and Sanabria domes and adjacent synforms. Capitals in black circles mark the location of P-T paths of figure 3. Based on Marcos et al. [1984, 2002 ; section 1a], Martíne $\mathbf{z}$ Catalán et al. [2003, 2004 ; section 1b] and Díe $\mathbf{z}$ Montes [2007; section 2]. The circle and dot symbol indicates a sense of movement to the reader in the Sanabria shear zone. See figure 1 for location of sections.

FIG. 2. - Coupes géologiques au travers des dômes de Lugo et Sanabria et des synformes adjacents. Les majuscules dans un cercle noir indiquent la localisation des trajectoires P-T dans la figure 3. D'après Marcos et al. [1984, 2002 ; coupe 1a], Martínez Catalán et al. [2003, 2004; coupe 1b] et Díez Montes [2007; coupe 2]. Le symbole avec un cercle et un point indique un sens de cisaillement vers le lecteur dans la zone de cisaillement de Sanabria. Voir figure 1 pour la localisation des coupes. 
The folds are well developed in the Armorican Quartzite, a $200-400 \mathrm{~m}$ thick competent layer that controlled the buckling processes during folding. These are commonly of the flattened parallel type [Ramsay, 1967]. An area where $\mathrm{C} 1$ folds crop out exceptionally well and have been little affected by subsequent deformations was selected in the southern limb of the Truchas synform to calculate the horizontal stretch associated to folding. Several orthogonal sections, ranging from individual metric folds to panoramic views, were analyzed first by estimating the superimposed flattening, then removing it, and finally measuring the length of the beds and comparing it with the final horizontal lengths. To estimate the superimposed flattening, we used dip isogons [Ramsay, 1967; Hudleston, 1973; Ramsay and Huber, 1987] and a modified version of the computer program Isogons [Vacas Peña, 2001].

The value obtained for the horizontal stretch, which is the ratio of deformed to undeformed lengths [Means, 1976] varies between 0.8 and $\mathbf{0 . 5}$, with a mean of $\boldsymbol{0 . 6 7}$. This includes shortening by buckling, plus superimposed flattening, but not initial layer-parallel shortening, which is difficult to estimate. These values have been obtained assuming that deformation was of the plane strain type, that is, no changes in the surface of the orthogonal sections occurred. This implies no significant volume change, and no elongation in the direction normal to the section. If these assumptions are generalize to the whole crust, a stretch of 0.67 is equivalent to a shortening of $33 \%$, and would result in a crustal thickening factor of 1.5 or $150 \%$.

For the Mondonedo nappe, fold analyses were carried out by Bastida [1981] and Martínez Catalán [1985] in Cambrian and Ordovician quartzites. Shortening perpendicular to the axial surfaces vary between 37 and $59 \%$, which, considering pure shear, implies thickening parallel to the axial surface between 158 and $243 \%$. As the axial surface is incline instead of vertical, these numbers o not translate directly into values for vertical thickening, but suggest that shortening was higher here than in the Truchas synform.

${ }^{40} \mathrm{Ar} /{ }^{39} \mathrm{Ar}$ dating of regional cleavage $\left(\mathrm{S}_{1}\right)$ yielded $359 \mathrm{Ma}$ to the south of Puebla de Sanabria and close to the allochthonous complex of Bragança, and $336 \mathrm{Ma}$ to the east of the Mondoñedo nappe, indicating the diachronous character of deformation and its progradation from west to east, that is, toward the external zones of the belt [Dallmeyer et al., 1997].

\section{Thrusting (C2)}

The second deformation is characterized by the movement of thrust sheets directed toward the external zones. Thrusts significant to our research are those associated to the emplacement of the allochthonous complexes, and the basal thrust of the Mondonedo nappe.

The allochthonous complexes were first place over the lower allochthon and in turn, it was thrust onto the autochthon carrying the allochthonous complexes piggyback and crosscutting the $\mathrm{Cl}$ folds in the footwall. In the Órdenes Complex, the largest and thickest of the allochthonous complexes (fig. 1), the cumulative thickness shown by the different units approaches $20 \mathrm{~km}$ including the lower allochthon [Martínez Catalán et al., 2002]. Taking into account that erosion has occurred since its emplacement, the allochthonous sheet should have been more than $20 \mathrm{~km}$ thick. However, as the Órdenes Complex occupy a more internal position than the domes we have studied, and the allochthon was presumably wedge-shaped tapering to the E, we would consider $20 \mathrm{~km}$ as the maximum thickness of the allochthonous sheet above the domes in the numerical models.

Pressure estimations were made by Arenas [1988, 1991] based on the composition of phengites in Silurian metapelites underlying the Cabo Ortegal Complex. The dominant phengite generation yielde $400{ }^{\circ} \mathrm{C}$ and $0.25-0.3 \mathrm{GPa}$ $(\approx 11 \mathrm{~km})$, interpreted as conditions after $\mathrm{C} 2$. An old generation of phengites whose composition suggests conditions of $325^{\circ} \mathrm{C}$ and $0.2 \mathrm{GPa}$ (equivalent to $7.5 \mathrm{~km}$ ), may well represent conditions after the $\mathrm{C} 1$ recumbent folding. The data imply that roughly $10-15 \mathrm{~km}$ of allochthon replace $5-10 \mathrm{~km}$ of the footwall, loading the autochthon only with $5-10 \mathrm{~km}$ of new crust.

Thrusting of the Mondonedo nappe followed the emplacement of the allochthonous complexes. Its basal thrust crosscut $\mathrm{C} 1$ recumbent folds in both the hanging wall and footwall units. A ductile shear zone $3 \mathrm{~km}$ thick occurs at the base of the Mondoñedo nappe (fig. 2), and has been related to nappe emplacement by Bastida et al. [1986], and Aller and Bastida [1993]. However, although a portion of shearing may be relate to thrusting, a significant part of it seems actually linked to subsequent extension [Martínez Catalán et al., 2004; Ayarza and Martínez Catalán, 2007].

From its presently preserved thickness (fig. 2), we infer that the Mondonedo nappe was more than $10 \mathrm{~km}$ thick when emplaced. The pressure estimated at the top of its relative autochthon in the Xistral tectonic window, between $\mathbf{0 . 2}$ and 0.4 GPa [Arenas and Martínez Catalán, 2003], suggests a reduced thickness during the emplacement. But its basal rocks had previously reache $0.9 \mathrm{GPa}, \approx 35 \mathrm{~km}$ [Reche et al., 1998], partly by the overburden of the allochthonous complexes. Consequently, the thrust sheet was considerably thinned by internal deformation and/or erosion prior to or during emplacement [Martínez Catalán et al., 2003].

The timing of thrusting was bracketed by Dallmeyer et al. $\left[1997 ;{ }^{40} \mathrm{Ar} /{ }^{39} \mathrm{Ar}\right.$ method] to be between 343 and $321 \mathrm{Ma}$. The older is the age of the thrust-related foliation in the lower allochthon, and the latter is the age of a thrust some $40 \mathrm{~km}$ to the east of the Mondoñedo nappe front. These ages show the diachronism and progradation of thrusting to the external zones. The Mondonedo thrust is not dated but, given its intermediate position, an age of 330-325 Ma seems reasonable.

\section{Extension and gravitational collapse (E1)}

Following the emplacement of the allochthon and thrust imbrication of the autochthon, a pervasive subhorizontal tectonic foliation $\left(\mathrm{S}_{2}\right)$ developed in the middle and lower parts of the autochthonous section linked to extension, as indicated by the presence of two conjugate extensional shear zones affecting the Mondonedo nappe and its autochthon (fig. 2). The crustal wedge between them escaped eastward, whereas the previous Barrovian metamorphic zones were thinned and the isograds approached each other in the upper shear zone.

Kinematic criteria demonstrate a non-coaxial component of deformation, and mostly indicate extension E-W, normal to the orogenic trend. In the autochthon, large blocks of thick and competent Xistral Quartzite were 
rotated during extension by domino-style boudinage just below the Mondoñedo basal thrust (fig. 2). The base of the nappe was sheared with a top-to-the east sense of movement, deforming synkinematic granitoids and showing that the nappe and its footwall were strongly overprinted by the El extensional event.

In Sanabria, a broad shear zone developed structurally below the biotite isograd, with characteristics similar to the lower extensional shear zone of the Lugo dome. The stretching lineation and kinematic criteria indicate top-tothe southeast sense of shearing, which here is roughly parallel to the orogenic trend.

The cause of extension was probably heat accumulation due to crustal thickening, although advection by mantle-derived rocks [Galán et $\boldsymbol{a}$ l., 1996] might also have contributed. Heat lowered the viscosity of the middle and lower crust, caused partial melting, and facilitated viscous flow that accommodated extension of the whole crust, probably in response to gravitational forces [Martínez Catalán et al., 2003, 2004].

The first extensional event has been dated in migmatites in the Sanabria dome at $311-314 \mathrm{Ma}$ [U-Pb ages in monazites; Díez Montes, 2007]. In the Lugo dome, timing of $E 1$ is constrained by age data of the Variscan granitoids, which will be described in a later section. Granite massifs deformed by the extensional shear zones range between 323 and $313 \mathrm{Ma}$, whereas undeformed, postkinematic massifs yield ages of 295-285 Ma [Fernández-Suárez et al., 2000]. If the deformed granitoids were strictly synkinematic, their age is that of El extension. If they preceded extension, their dating provide a maximum age limit for E1, with a minimum age limit at $295 \mathrm{Ma}$ in any case.

Comparable granitoids in the Sanabria dome are little deformed to undeformed by E1, but can be affected by C3 strike-slip shear zones [Vegas et al., 2001]. The fact that synkinematic granitoids are often affected by subhorizontal foliations in the Lugo dome [Martínez Catalán, 1985; Bastida et al., 1986; Aranguren and Tubía, 1992] suggests that E 1 extension is younger there than in Sanabria. This would imply progradation of extension toward the external zones, which is congruent with the progradation to the east of contractional events C1 and C2 [Martínez Catalán et al., 2007].

\section{Late folding (C3)}

The third contractional deformation is characterized by upright folding, closely related to the contemporaneous activity of subvertical shear zones with wrench, mostly dextral components [Iglesias Ponce de León and Choukroune, 1980; Martínez Catalán et al., 2007].

Late C3 folds can be identified by their associated crenulation cleavage $\left(S_{3}\right)$ and because they fold the metamorphic isograds. They are upright to vertical, well developed and tight in the O11o de Sapo antiform, but in the core of the Sanabria dome, the C3 Dradelo folds are overturned and even recumbent, due to overprinting by the dome (fig. 2). In both cases, $\mathrm{C} 3$ folds overprint the extensional foliation $\left(S_{2}\right)$. However, C3 folds are rare and open in the Lugo dome, which suggests that the main extension occurred here after the C3 event.

Probably, late folding did not induce significant crustal thickening, because it is associated with an horizontal stretching lineation and related to strike-slip movements. The fact that it occurred during the extensional collapse implies renewed shortening, probably related to oblique plate convergence. However, the crust was weak and did not allow contractional stresses to build up a new significant crustal root, so that shortening was mostly resolved by horizontal flow.

The age of late folding has been established at $314 \pm 6 \mathrm{Ma}$ by dating synkinematic granitoids [Capdevila and Vialette, 1970; Ries, 1979], and at 315 and $305 \mathrm{Ma}$ by dating the motion of strike-slip shear zones [Regêncio Macedo, 1988; Valle Aguado et al., 2005]. These ages partially overlap those of E1 extension, and suggest that C3 folding was an isochronous contractional event intercalated in a longer and diachronous episode of orogenic collapse and extension.

\section{Late extension and doming (E2)}

Late stages of collapse and extension are characterized by doming and the late development of the Viveiro and Chandoiro normal faults (fig. 2). We suggest that the domes were formed by lateral flow and ascent of ductile, low-density migmatitic gneisses, as proposed for this kind of structures by Block and Royden [1990], Tirel et al. [2004], and Whitney et al. [2004], but possibly coinciding with weakened areas subjected to renewed extension. The normal faults would represent the transition from ductile to brittle behaviour in the very late stages of extension.

E 1 and E2 extensional events together were responsible for the return of the Variscan crust to a normal thickness. The difference in the maximum pressure registered by rocks cropping out in both sides of the Viveiro fault was estimated by Reche et al. [1998] using thermobarometry, to be 0.4-0.5 GPa, roughly equivalent to $15-19 \mathrm{~km}$. This offset results from the combined effect of the two conjugate extensional shear zones joining each other close to the fault, and the fault itself. A throw of $5-6 \mathrm{~km}$ is more reasonable for the Viveiro fault alone [Martínez Catalán et al., 2003], and a similar throw can be assumed for the Chandoiro fault [Díez Montes, 2007].

Timing of E2 is constrained by ${ }^{40} \mathrm{Ar} /{ }^{39} \mathrm{Ar}$ cooling ages around $300 \mathrm{Ma}$ in the Lugo dome [Dallmeyer et al., 1997], and by the Veiga granodiorite in Sanabria, dated at $286 \pm 6 \mathrm{Ma}$ [Ortega et al., 2000], and deformed and cut by the Chandoiro fault [Román-Berdiel et $\boldsymbol{a}$ l., 1995], so dating latest stages of dome development.

\section{METAMORPHIC EVOLUTION}

\section{Lugo dome}

Metamorphism in the Lugo dome was first described by Capdevila [1969] as of intermediate-low pressure type. It was further studied by Reche et al. [1998], who carried out thermobaric calculations, and by Arenas and Martínez Catalán [2003], who traced P-T paths for the Mondoñedo nappe and its autochthon (fig. 3A) using mineral associations and the petrogenetic grid for pelites of Powell and Holland [1990].

In the Mondoñedo nappe, a classic Barrovian succession including the chlorite, biotite, almandine and staurolite zones point to an initial gradient of intermediate pressure. Kyanite occurs sparsely, and has been found as a relict phase in the sillimanite-orthoclase zone, in the sheared rocks close to the Viveiro fault and in a few points of the biotite zone. A later 
low-pressure gradient is indicated by garnet and staurolite-bearing rocks entering into the sillimanite and andalusite fields. The P-T paths (fig. 3A, paths A to E) evolved along the intermediate pressure field during prograde metamorphism, related to crustal thickening (dashed, unconstrained part of paths $\mathrm{A}$ and $\mathrm{B}$ ). Then, they show a strong decompression and enter into the low pressure field. Reche et al. [1998] describe kyanite developed after andalusite in Ordovician and Silurian metapelites surrounding the Viveiro fault, but this transformation was not included in the P-T paths of Arenas and Martínez Catalán [2003] shown in figure $3 \mathrm{~A}$.

For the relative autochthon of the nappe (grey arrows $\mathrm{F}$ to I, fig. 3A), the P-T paths were traced always in the low pressure field, because of the absence of kyanite, scarcity of garnet, and abundance of cordierite. The upper part of the footwall to the nappe was in the chlorite-biotite zone during thrusting, whereas deeper zones reached the staurolite zone, sometimes accompanied by garnet. Cordierite was also profusely developed in these rocks. Still deeper, the sillimanite and sillimanite-orthoclase zones were reached. The low slope and prograde character of the paths suggest a strong heat source, and Arenas and Martínez Catalán [2003] suggested that a detachment underlay the deep parts of the footwall unit, because isobaric heating may occur in the hanging wall to extensional detachments. We will see that these paths and the presence of an underlying detachment are not supported by the thermal models.

\section{Sanabria deme}

The metamorphic evolution was studied by Díez Montes [2007] and is summarised in figure 3B (arrows J to M). The evolution does not differ greatly from that of the Lugo dome, but in Sanabria, the voluminous Ollo de Sapo Fm, of quartzo-feldspathic composition, makes it difficult to trace several of the isograds as they are characteristic of metapelites. A garnet zone cannot be traced, although this phase is common in the sillimanite-orthoclase zone. As in the Mondoñedo nappe, kyanite occurs only in a few points of the biotite zone, and as a relict phase in the sillimanite-orthoclase zone

Four P-T paths were drawn by Díez Montes [2007] for different metamorphic zones using the same petrogenetic grid as for the Mondoñedo nappe and thermobaric calculations. Two of them ( $\mathrm{K}$ and $\mathrm{L}$ ) are for the same stratigraphic level, Early Ordovician slates, but in the northern and southern limbs of the dome respectively. Note that only the biotite zone was reached in the north whereas the south went into the sillimanite zone.

The initial prograde path is considered of somewhat lesser pressure than in the Mondoñedo nappe, due to the scarcity of garnet, but in a given moment, the Sanabria region was buried and kyanite grew in Early Ordovician aluminous slates of the biotite zone. This was probably due to the emplacement of the allochthonous complexes and is marked by a step in paths $\mathrm{K}$ and $\mathrm{M}$. Deep parts of the dome were subsequently decompressed, entering the sillimanite-orthoclase zone and undergoing retrogression through the andalusite zone (path $\mathrm{M}$ ) during extension and thinning. Temperatures obtained there using thermobarometry range between 500 and $650^{\circ} \mathrm{C}$. Upper parts sustained apparently no decompression, and were heated reaching the sillimanite zone before undergoing retrogression (path L). According to Díez Montes [2007], paths L and M would reflect respectively upper and lower levels of the E1 shear zone, demonstrating its extensional character (fig. 2).

\section{GRANITE INTRUSIONS}

Three main groups of Variscan granitoids occur in Northwest Iberia [Capdevila, 1969; Capdevila and Floor, 1970]. The oldest consists of metaluminous, biotite-rich synkinematic granodiorites, poor in fluid phases and showing tonalitic facies and enclaves. They are allochthonous in relation to their country rocks, derive from partial melting of the lower crust [Capdevila, 1969], and include a mantle contribution [Galán et $\boldsymbol{a l}$., 1996]. The crystallisation age of one of them in the Lugo dome is $323_{-5}^{+9}$ Ma [Fernández-Suárez et al., 2000], so that, by that time, the temperature reached by the
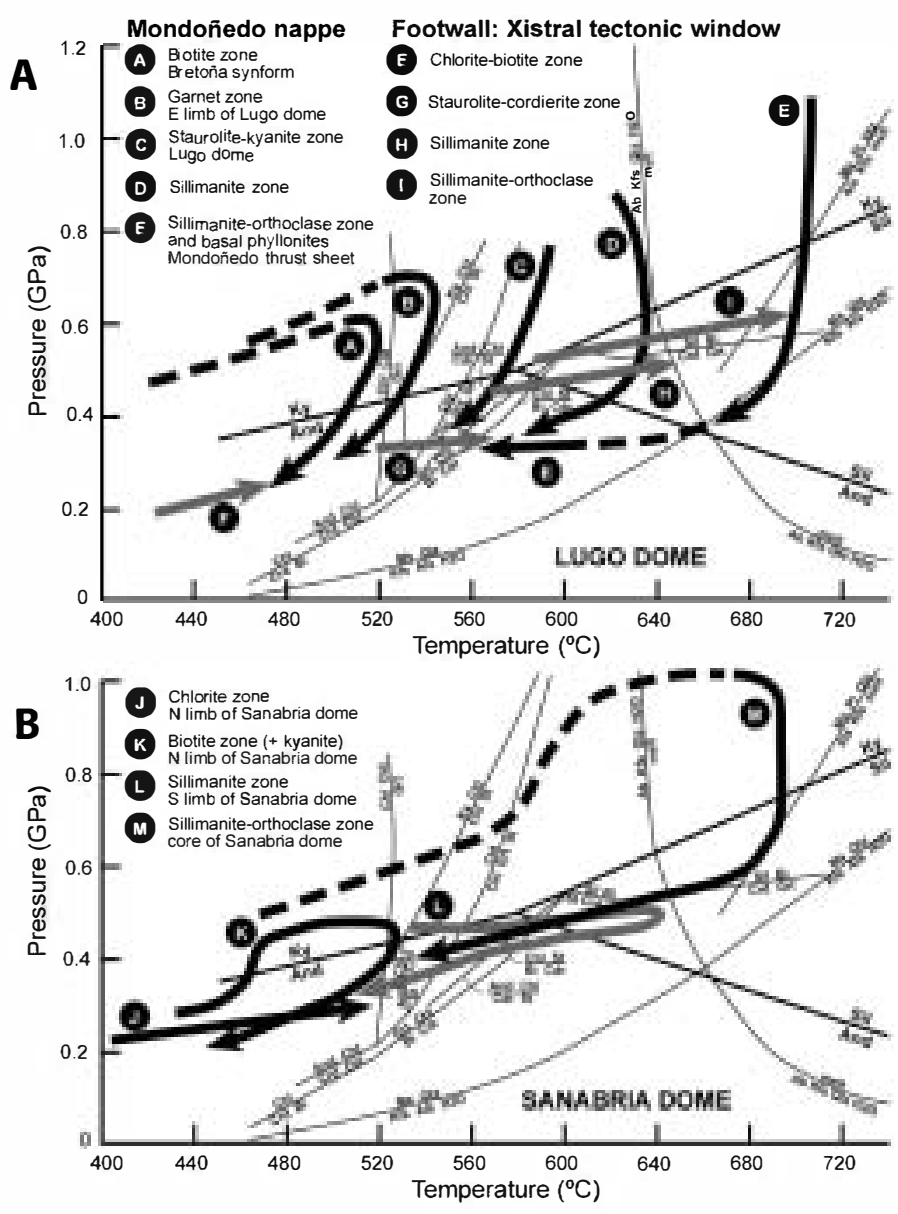

FIG. 3. - P-T paths for the Lugo dome (A), and the Sanabria dome (B), after Arenas and Martínez Catalán [2003] and Díez Montes [2007] respectively. Curves of mineral equilibrium according to Powell and Holland [1990] for the pelitic system, and to Luth et al. [1964], Le Breton and Thompson [1988] and Chatterjee and Johannes [1974], for the minimum melting in the hydrous granitic system, and for the disappearance of muscovite. The location of the different paths is shown in figure 2 .

FIG. 3. - Trajectoires P-T pour les dômes de Lugo (A) et Sanabria (B), d'après Arenas et Martínez Catalán [2003] et Díez. Montes [2007] respectivement. Courbes d'équilibre selon Powell et Holland [1990] pour le système pélitique, et selon Luth et al. [1964], Le Breton et Thompson [1988] et Chatterjee et Johannes [1974], pour la fusion minimale dans le système granitique hydraté et la disparition de la muscovite. La position des trajectoires est marquée sur la figure 2. 
lower crust should have been high enough to generate tonalitic melts, probably by melting of biotite and/or amphibole.

The second group consists of synkinematic, peraluminous, two-mica granites, rich in fluid phases and metasedimentary enclaves. They derive from metasediments, and their character vary from subautochthonous to allochthonous in relation to the country rocks. Two U-Pb ages of $317_{-5}^{+9}$ Ma and $313 \pm 2$ Ma were obtained by Fernández-Suárez et al. [2000] in massifs of the Lugo dome. In this case, the middle crust should have reached the temperature necessary to generate melts of granitic (monzogranites, adamellites) composition at that time, probably by melt-producing reactions driven by the decomposition of muscovite.

The third group includes a wide range of compositions, from granodiorite to monzogranite and adamellite, with the common characteristic of being postkinematic and clearly allochthonous, often intruding in upper crustal levels. Postkinematic granitoids have been dated by the U-Pb method
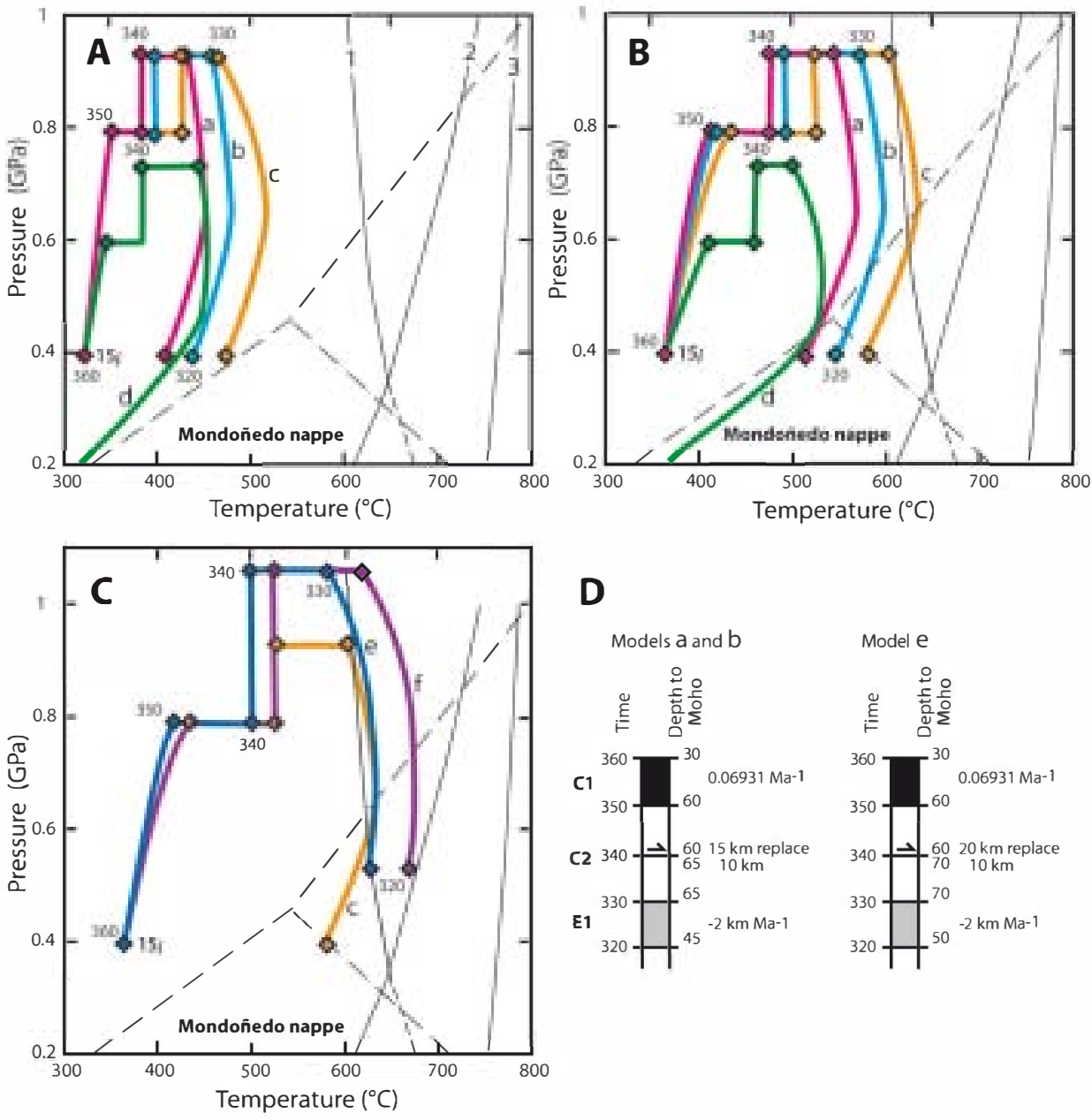

D
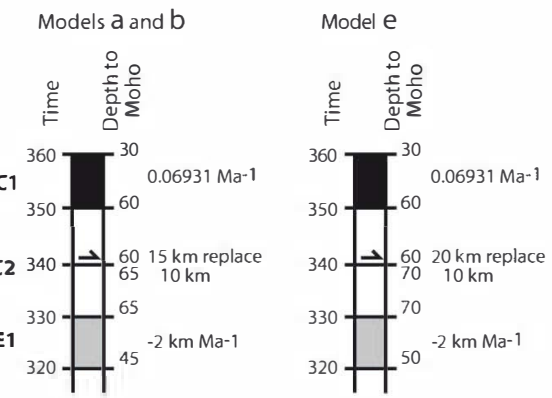

FIG. 4. - Thermal models of the Mondoñedo nappe used to identify general conditions consistent with geological data. - A: radiogenic heat production evenly distributed through the upper $15 \mathrm{~km}$, contributing to the surface heat flux with $30 \mathrm{~mW} \mathrm{~m}^{-2}$. P-T-t paths follow the temperature change in rocks initially $15 \mathrm{~km}$ deep (15i) that underwent: a-homogeneous thickening of entire lithosphere, b- thickening limited to the crust, c- thickening limited to upper $20 \mathrm{~km}$ of crust, all by a factor of 2 ; and d-thickening of upper $20 \mathrm{~km}$ by a factor of 1.5 . The allochthonous complexes are $15 \mathrm{~km}$ thick and replace the upper $10 \mathrm{~km}$ of the footwall. - B: similar to A, but with a contribution of $40 \mathrm{~mW} \mathrm{~m}^{-2}$ to surface heat flux. - C: radiogenic heat production with flux of $40 \mathrm{~mW} \mathrm{~m}^{-2}$ at the surface, and homogeneous thickening by factor of 2. In paths e and $\mathrm{f}$ the allochthon is $20 \mathrm{~km}$ thick and replaces upper $10 \mathrm{~km}$ of footwall. In path e the entire crust is thickened while in $\mathrm{f}$ thickening is limited to the upper $20 \mathrm{~km}$; $\mathrm{c}$-repeats model $\mathrm{c}$ from previous figure. Points on the paths indicate time intervals of $10 \mathrm{Ma}$. Reactions curves are 1: pelite minimum melt, 2: muscovite dehydration melting [Thompson, 2001], 3: biotite dehydration melting [Le Breton and Thompson, 1988]. Stability fields for the aluminosilicate polymorphs according to Powell and Holland [1990]. - D: model structural changes through time are presented as a record of crustal thickness (depth to the Moho in $\mathrm{km}$ ), timing of orogenic events (age in Ma), and strain rates (see text). Only models a, b, and e have been represented. Similar model representation is used in figures 5 , 6 and 8 .

FIG. 4. - Modèles thermiques de la nappe de Mondoñedo utilisés pour établir les conditions générales en concordance avec les données géologiques. - A : chaleur radiogénique produite de façon homogène dans les $15 \mathrm{~km}$ supérieurs, contribuant au flux de chaleur à la surface pour $30 \mathrm{~mW} \mathrm{~m}^{-2}$. Les trajectoires P-T-t montrent l'évolution thermique des roches qui étaient à l'origine à $15 \mathrm{~km}$ de profondeur (15i), et ont subi : a-épaississement de toute la lithosphère, b-épaississement limité à la croûte, c-épaississement limité aux $20 \mathrm{~km}$ supérieurs de la croûte, tous par un facteur de 2, et $\mathrm{d}-$ épaississement des $20 \mathrm{~km}$ supérieurs de la croûte par un facteur de 1,5. Les complexes allochtones ont une épaisseur de $15 \mathrm{~km}$ et remplacent les $10 \mathrm{~km}$ supérieurs de l'autochtone relatif. - B : comme A mais avec une contribution au flux de chaleur à la surface de $40 \mathrm{~mW} \mathrm{~m}^{-2}$ et - C : chaleur radiogénique produisant un flux de chaleur à la surface de $40 \mathrm{~mW} \mathrm{~m}^{-2}$ et un épaississement homogène par un facteur de 2. Dans les trajectoires e et f, l'allochtone a $20 \mathrm{~km}$ a'épaisseur et remplace $10 \mathrm{~km}$ d'autochtone. Dans e, toute la croûte a été épaissie, tandis que dans f, l'épaississement est limité aux $20 \mathrm{~km}$ supérieurs; c- est comme le modèle $c$ de la figure précédente. Les points sur les trajectoires indiquent des intervalles de 10 million d'années. Les courbes des réactions sont 1 : fusion minimale des pélites, 2 : fusion avec déshydratation et disparition de muscovite [Thompson, 2001 ], $3:$ fusion avec déshydratation et disparition de biotite [Le Breton et Thompson, 1988]. Champs de stabilité des silicates d'aluminium d'après Powell et Holland [1990]. - D : les changements structuraux dans les modèles à travers du temps sont représentés comme un enregistrement de l'épaisseur crustale (profondeur du Moho en km), âge des événements orogéniques (en million d'années) et vitesses de déformation (voir texte). Seulement les modèles a, b et e ont été représentés. On utilise la même représentation 
between 295 and $285 \mathrm{Ma}$ [Fernández-Suárez et al., 2000], and by the ${ }^{40} \mathrm{Ar} /{ }^{39} \mathrm{Ar}$ method between 285 and $275 \mathrm{Ma}$ [Dallmeyer et al., 1997]. U-Pb data are considered more reliable for crystallisation ages.

Granite generation in an orogenic context implies that the continental crust is hot enough as to undergo partial melting. A hot crust is also the condition require to initiate the extensional collapse [England and Thompson, 1986; Burg et al., 1994]. Consequently, timing of granite emplacement is an important tool to test the validity of numerical models. Furthermore, Galán et al. [1996] have found a mantle contribution in the first group of granitoids, whereas Fernández-Suárez et $\boldsymbol{a l}$. [2000], have proposed that the third group of granitoids result from delamination at the end of the Variscan Orogeny. Thermal modeling may estimate the need of mantle involvement and its extent.

\section{THERMAL CONSTRAINTS}

According to England and Thompson [1984], thermal equilibrium in passive continental margins is reached in about $60 \mathrm{Ma}$. In Northwest Iberia, thermal relaxation took place between the intrusion of Early Ordovician granitoids [470 Ma; Lancelot et al., 1985; Valverde-Vaquero and Dunning, 2000] plus very limited Silurian volcanism [420 Ma; Ancochea et al., 1988], and the first Variscan deformation event [360 Ma]. Consequently, we may consider that the crust had been thermally re-equilibrated before the onset of the Variscan collision. The thick Cambrian to Early Devonian platform-facies succession indicates thermal subsidence, confirming cooling of the margin prior to the orogeny.

For the heat flow, a value of $60 \mathrm{~mW} \mathrm{~m}^{-2}$ is suggested by England and Thompson [1984] for the Neoproterozoic and Paleozoic continental crust, with $30 \mathrm{~mW} \mathrm{~m}^{-2}$ supplied by the mantle and $30 \mathrm{~mW} \mathrm{~m}^{-2}$ originate in the upper $15 \mathrm{~km}$ as radiogenic heat. More precisely, Fernández et al. [1998] have found a mean heat flow of $71 \mathrm{~mW} \mathrm{~m}^{-2}$ for the Iberian Massif, the Variscan basement of Iberia. These authors also calculated the rate of radiogenic heat production in basement rocks, with values between $1.5-3.5 \mu \mathrm{W} \mathrm{m}{ }^{-3}$ in metasediments of the autochthon of Northwest Iberia (mean of $2.25 \mu \mathrm{W} \mathrm{m}{ }^{-3}$ ) and 0.9-4.7 $\mu \mathrm{W} \mathrm{m}^{-3}$ in granitoids of the whole Iberian Massif (mean of $3.26 \mu \mathrm{W} \mathrm{m}{ }^{-3}$ ). Assuming constant heat production in the uppermost $15 \mathrm{~km}$ of crust, the radiogenic contribution to the heat flow there will be of $35 \mathrm{~mW} \mathrm{~m}^{-2}$ for the metasediments and $50 \mathrm{~mW} \mathrm{~m}^{-2}$ for the granitoids. As Variscan granitoids are the product of reworking of older crust, and no new radiogenic sources were incorporated to the autochthon during or after the Variscan Orogeny, the present high radiogenic contribution can be extrapolated to the time of Variscan deformation.

Accordingly, a value of $70 \mathrm{~mW} \mathrm{~m}^{-2}$ is reasonable for the autochthonous continental crust at the time of Variscan deformation, with $30 \mathrm{~mW} \mathrm{~m} \mathrm{~m}^{-2}$ supplied by the mantle and $40 \mathrm{~mW} \mathrm{~m}^{-2}$ originated in the crust. Tests were carried out using either a homogeneous distribution of heat production in the upper $15 \mathrm{~km}$ of the crust, or an exponential decrease in heat production with depth for the whole crust. The thermal evolutions were similar, suggesting that the way in which the radiogenic heat production decreases with depth does not affect the models very much, providing that it is high in the upper crust and zero at its base. Much more important is the total heat flux delivered to the surface. The final models used homogeneous heat production in the upper $15 \mathrm{~km}$, which corresponds to a mean radiogenic heat production of $2.67 \mu \mathrm{W} \mathrm{m}{ }^{-3}$ in the upper crust.

The allochthonous complexes include abundant metasediments and granitoids, sources of radiogenic heat production, but as they consist also of lower crustal units, ophiolites, and mantle, their contribution may be smaller. A value of $55 \mathrm{~mW} \mathrm{~m}^{-2}$ will be taken, $25 \mathrm{~mW} \mathrm{~m}^{-2}$ of which derive from radiogenic heat.

Other parameters have been chosen as follows. For the thermal conductivity of the crust, a value of $2.25 \mathrm{~W} \mathrm{~m}^{-1} \mathrm{~K}^{-1}$ has been used based on England and Thompson [1984]. The arithmetic mean of 68 values measured in wells of the Iberian Massif yields $2.86 \mathrm{~W} \mathrm{~m}^{-1} \mathrm{~K}^{-1}$ [Fernández et al., 1998], but these correspond to the present crystalline basement, quite different to the sedimentary pile existing at the beginning of Variscan deformation. For the mantle, we use a value of $3.3 \mathrm{~W} \mathrm{~m}^{-1} \mathrm{~K}^{-1}$ [Turcotte and Schubert, 1982]. The specific heat capacity of rocks is assumed to be $1000 \mathrm{~J}$ $\mathrm{kg}^{-1} \mathrm{~K}^{-1}$ [Turcotte and Schubert, 1982; Peacock, 1989; Stüwe, 2002], whereas the densities of crust and lithospheric mantle have been fixed at $2700 \mathrm{~kg} \mathrm{~m}^{-3}$ (upper crust), $2900 \mathrm{~kg} \mathrm{~m}^{-3}$ (lower crust) and $3260 \mathrm{~kg} \mathrm{~m}^{-3}$ (mantle). With these values, thermal diffusivity is $8.33 \times 10^{-7} \mathrm{~m}^{2} \mathrm{~s}^{-1}$, $7.76 \times 10^{-7} \mathrm{~m}^{2} \mathrm{~s}^{-1}$, and $1 \times 10^{-6} \mathrm{~m}^{2} \mathrm{~s}^{-1}$ respectively. Finally, the bottom of the lithosphere has been placed to coincide with the $1300{ }^{\circ} \mathrm{C}$ isotherm, based on Parsons and McKenzie [1978], and McKenzie and Bickle [1988]. Details of parameters use are given in table I.

\section{STRAIN RATES AND DEFORMATION-TIME SCHEMES}

Our aim is not to improve the methodology to carry out thermal modeling as established by England and Thompson [1984] and Peacock [1989], but to apply it to real cases. However, as in the real world deformation is not instantaneous, and we have some time constraints available, we introduce homogeneous progressive deformation in our models instead of the instantaneous crustal thickening used by the pioneers.

When ductile deformation is involved in the models, thickening or thinning during a given time interval can be incorporate by using a strain rate. For one dimensional models, only changes in the length of vertical lines must be considered. The parameter commonly used is the elongation $(e)$, define as the change in length of a line in relation to its original length: $e=\left(l_{f}-l_{\bullet}\right) / l_{\bullet}$, where $l_{\bullet}$ and $l_{\mathrm{f}}$ are the initial and final lengths respectively [Means, 1976].

However, for progressive deformation, elongation increments must be considered, and the smaller the increments, the better is the value obtained for the finite strain. The most precise option is to use a parameter called natural strain, which is an integrate infinitesimal elongation [Means, 1976]: $\bar{e}=\int d l / l=\ln \left(l_{f} / l_{\bullet}\right)=\ln (1+e)$.

The natural strain rate then will be: $\dot{e}=\ln \left(l_{f} / l_{\bullet}\right) / \Delta t=\ln (1+e) \Delta t$

As $\ln \left(l_{f} / l_{0}\right)=\Delta t \cdot \dot{e}$, the depth of any point after a finite time interval $(\Delta t)$ will be: $l_{f}=l_{\bullet} \cdot \exp (\dot{e} \cdot \Delta t)$, or $z=z_{0} \cdot \exp (\dot{e} \cdot \Delta t)$ when calculated using the initial depth $\left(z_{0}\right)$ and the time passed since deformation started. Using the 


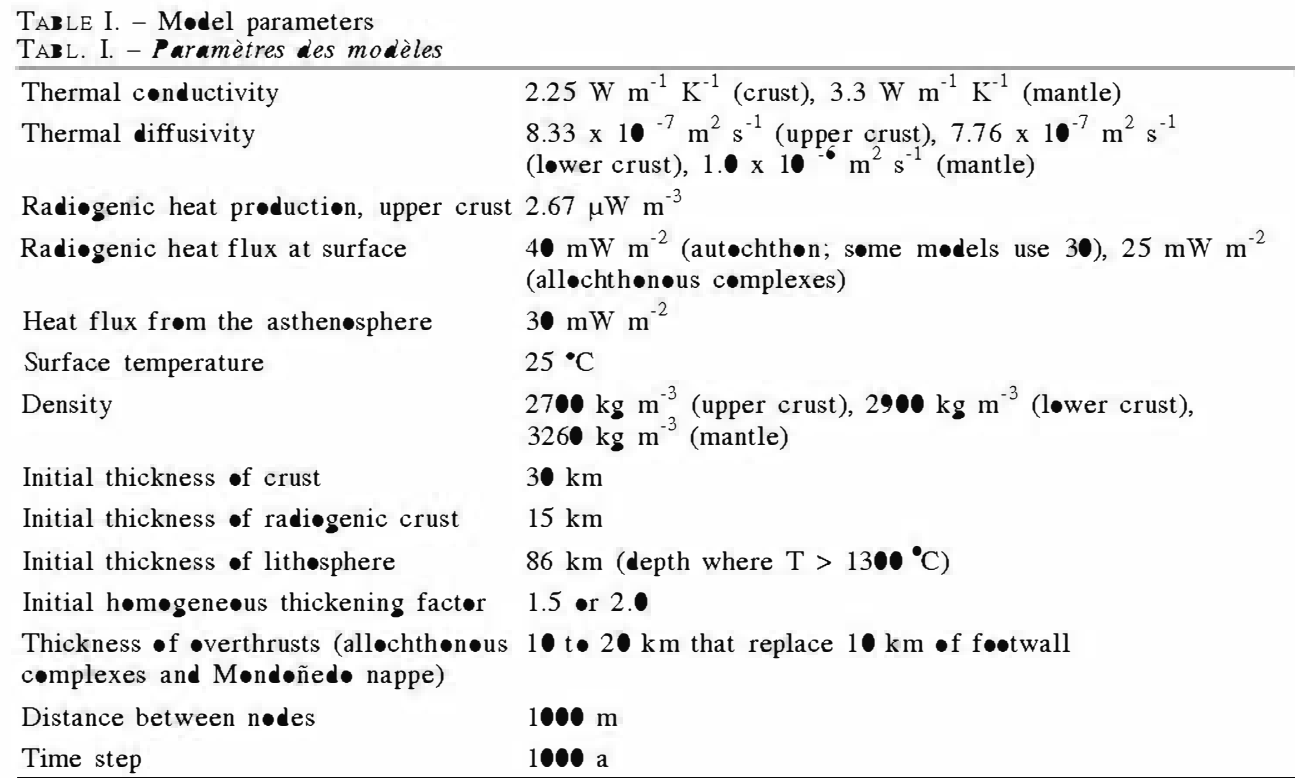

depth before the last increment $\left(z_{\mathrm{n}-1}\right)$, the new depth will be: $z_{n}=z_{n-1} \cdot \exp (\dot{e} \cdot \Delta t)$, with $\Delta t$ now being the time interval between successive increments. We have used time increments of 1000 years in the models.

Progressive ductile deformation is shown in the time schemes that accompany the results of numerical models by a time interval filled in black for crustal thickening and grey for crustal thinning, and by the value of the natural strain rate $(\dot{e})$ in $\mathrm{Ma}^{-1}$. For instance, $0.06931 \mathrm{Ma}^{-1}$ means that a crust $30 \mathrm{~km}$ thick doubles its thickness in 10 million years: $\dot{e} \cdot \Delta t=0.06931 \cdot 10=0.6931$, and $30 \cdot \exp (0.6931)=60 \mathrm{~km}$.

For thrusting, the effect of heating induced by the thrust sheet in its footwall unit is difficult to model in a progressive way. For that reason, thrusts are modelled as instantaneous, following England and Thompson [1984], and a time for thermal relaxation will be included before or/and after thrusting, to compensate for the fact that thrust motion actually occurs along a finite time interval. Shear heating is not contemplated.

England and Thompson [1984] modelled thrusting by adding the thrust thickness to the previous thickness of the crust. This would be correct for thrusts using the Earth surface to glide, but most thrusts are dipping faults intersecting Earth surface at their fronts, where thrust sheets are supposed to be eroded as they move. In our case, the proof that neither the allochthonous complexes, nor the Mondonedo nappe were thrust over the Earth surface is that their relative autochthons had previously reached the chlorite zone and had developed the $S_{1}$ cleavage. This implies that thrusting carried deep rocks to a higher position, and that rocks initially above the present autochthon were removed by the same thrust fault. For that reason, we will use a replacement mode for thrusts. The change in depth of any point or node below the thrust will be given by: $z_{n}=z_{n-1}+\Delta c$, where $\Delta c$ is the added thickness in $\mathrm{km}$, which equals the thickness of the thrust sheet minus the thickness of the footwall crust it replaces. Thrusts are shown in the time schemes by a line with an arrow, and indicated by an expression like " $20 \mathrm{~km}$ replace $10 \mathrm{~km}$ ", meaning that a thrust sheet $20 \mathrm{~km}$ thick replaces $10 \mathrm{~km}$ of its footwall, adding only $10 \mathrm{~km}$ of overburden.
Normal detachment faults do not include any external heat source, as is the case for thrusts, because a portion of crust is subtracted from the modeled vertical column instead of being added. Their motion can be modelled as progressive, simply changing the depths below them according to: $z_{n}=z_{n-1}-u \cdot \Delta t$, where $-u$ is the rate of uplift or exhumation. No changes in depth occur above the fault, and nodes initially below it are eliminate as they become shallower than fault depth. Normal detachments are indicated in the time schemes by a grey filling (the same as for extensional ductile deformation), and by the exhumation rate in $\mathrm{km}$ per million years (e.g.: $-1 \mathrm{~km} \mathrm{Ma}^{-1}$ ). The expression " $\mathrm{z}>10 \mathrm{~km}$ " indicates that fault depth is $10 \mathrm{~km}$ and only points beneath that depth move upwards.

Finally, progressive erosion can be modeled in the same way as the footwall to extensional detachments, with the same equation: $z_{n}=z_{n-1}-u \cdot \Delta t$ but applied to all depths. In that case, the exhumation rate in $\mathrm{km}$ per $\mathrm{Ma}$ is indicated.

\section{MODELING PROCEDURE}

Thermal regimes and their change through time have been calculated using a one-dimensional finite-difference model [Peacock, 1989, 1990, 1991] that tracks position and temperature of nodes during deformation and the thermal response to deformation. For the models tested, an initial geotherm for a $30 \mathrm{~km}$ thick crust was calculated using a heat flux of $30 \mathrm{~mW} \mathrm{~m}^{-2}$ from the asthenosphere to mantle lithosphere and an additional $40 \mathrm{~mW} \mathrm{~m}^{-2}$ (or rarely $30 \mathrm{~mW}$ $\mathrm{m}^{-2}$ ) delivered to the surface as heat generated by decay of radiogenic elements distributed evenly through an upper layer of the crust, initially $15 \mathrm{~km}$ thick. This results in a surface heat flux of $70 \mathrm{~mW} \mathrm{m^{-2 }}$.

The model crust is then subjected to a series of deformations that include homogeneous thickening (to simulate $\mathrm{C} 1$ crustal thickening contemporaneous with recumbent folding) and overthrusting replacing a portion of the crust (to model $\mathrm{C} 2$, the emplacement of the allochthonous complexes and the Mondoñedo nappe). Thickening is followed 
by thermal relaxation and then by homogeneous thinning (E1 extensional ductile shear zones) that returns the Moho to a depth of between 40 and $50 \mathrm{~km}$. In addition, $5 \mathrm{~km}$ of crust is removed by an upper-crustal detachment (E2, simulating the Viveiro and Chandoiro faults) in some models. In most models only the crust is thickened; however, in all cases thinning is assumed to affect the entire lithosphere.
We prefer to model deformations such as homogeneous thickening and thinning as processes that occur at rates consistent with geological strain and have modelled and tracked model movements using natural strain. This approach tends to produce P-T-t paths with a more realistic appearance than those that result from models that use instantaneous change. However, the end result, that is thermal
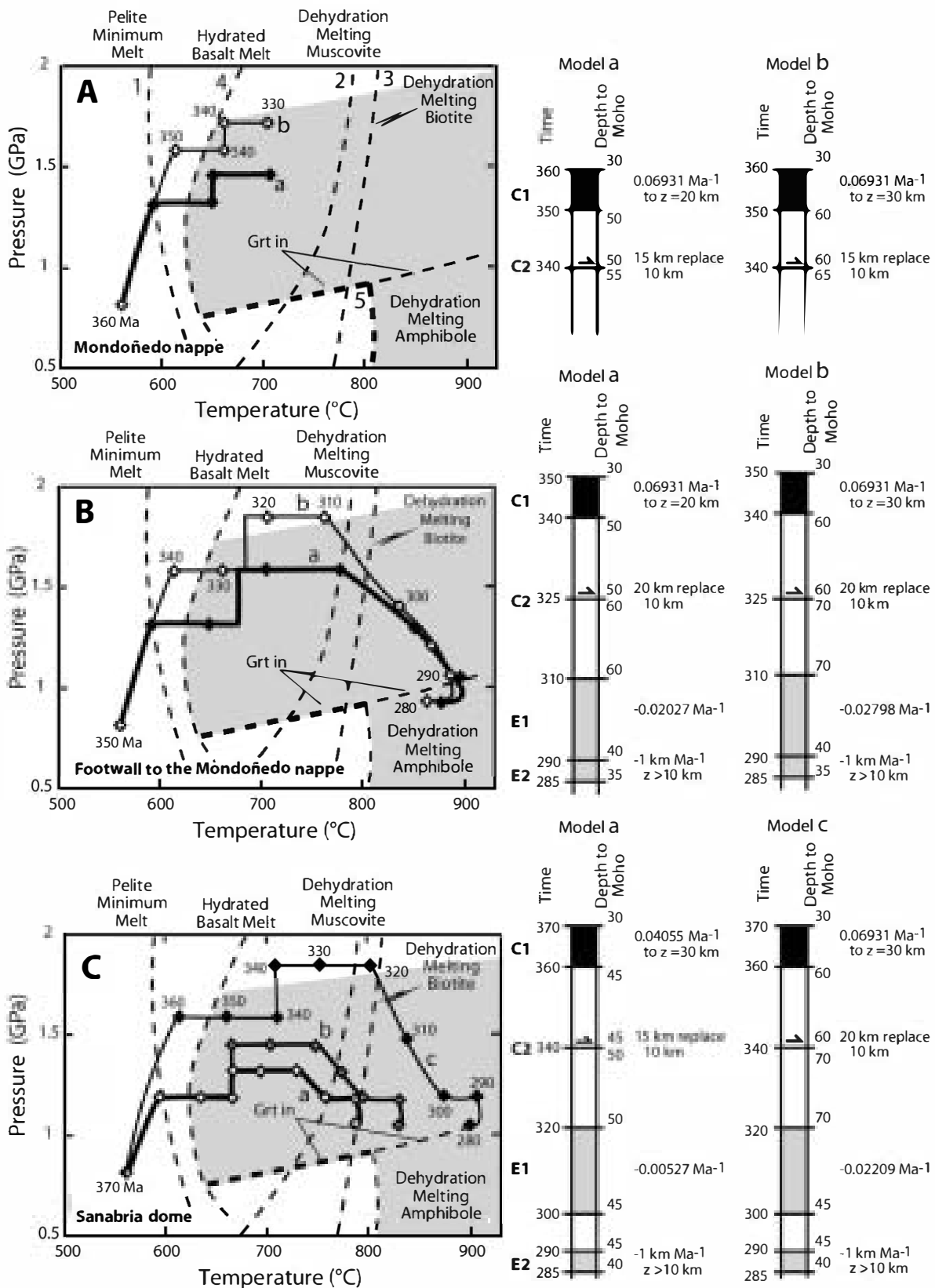

FIG. 5. - Model results showing the thermal effect of thickening on the Moho. Dynamo-thermal models intended to represent orogenic thickening and thinning should be consistent with the production of lower crustal melts (grey area) at model times of 30 and 60 Ma.- A: Mondoñedo nappe.- B: Footwall to the Mondoñedo nappe at the Xistral tectonic window, Lugo dome.- C: Sanabria dome. Structural changes during orogeny are given to right of model results. Model b in C is similar to model a, but with a $20 \mathrm{~km}$ thick allochthon replacing the upper $10 \mathrm{~km}$ of crust at its footwall. Reaction curves 1,2 , and 3 as in figure 4. Other reactions are 4: melting of basalt, and 5: dehydration melting field for amphibole and the garnet-in reaction for basaltic amphibolites [Rapp and Watson, 1995]. In this and the following figures, radiogenic heat production is initially distributed through the upper $15 \mathrm{~km}$, contributing to the surface heat flux with $40 \mathrm{~mW} \mathrm{~m}^{-2}$, and time is shown in Ma only for the P-T-t path reaching the highest pressure.

FIG. 5. - Modèles montrant l'effet thermique de l'épaississement dans le Moho. Les modèles dynamo-thermiques simulant l'épaississement et l'amincissement orogéniques doivent fournir la production des liquides dans la croûte inférieure après 30 et $60 \mathrm{Ma}$ - A : nappe de Mondoñedo. - B : autochtone de la nappe de Mondoñedo dans la fenêtre tectonique de Xistral, dôme de Lugo. - C : dôme de Sanabria. L'histoire structurale pendant l'orogenèse est montrée à droite. Le modèle b dans C est comme le modèle a sauf que $20 \mathrm{~km}$ d'allochtone remplacent les $10 \mathrm{~km}$ supérieurs de l'autochtone relatif. Courbes des réactions 1, 2 et 3 comme sur la figure 4. D'autres réactions sont $4:$ fusion du basalte, et 5 : fusion avec déshydratation pour amphibole et la réaction produisant a grenat dans des amphibolites basaltiques [Rapp et Watson, 1995]. Dans cette figure et les figures suivantes, la chaleur radiogénique est au début distribuée de façon homogène dans les $15 \mathrm{~km}$ supérieurs, contribuant au flux de chaleur à la surface pour $40 \mathrm{~mW} \mathrm{~m}^{-2}$. Le temps est montré seulement pour la trajectoire atteignant la plus haute pression. 
conditions in the lithosphere, is little changed by this aspect of the models and within a few million years resulting differences are small and are within error introduced by estimates of parameters used to compute thermal relaxation and estimates of the timing of deformational events based on geochronology.

For initial crustal thickening, we have used age data of Dallmeyer et al. [1997] and taken into account the diachronous character of $\mathrm{C} 1$ deformation. We have considered an interval of $10 \mathrm{Ma}$ for this event, and progressive younging toward the external zones: $370-360 \mathrm{Ma}$ in Sanabria, 360-350 Ma in the Mondoñedo nappe and 350-340 Ma in its autochthon.

We have treated thrusting as an instantaneous event. Emplacement of the allochthonous complexes above the
Mondoñedo nappe and above the autochthon of the Sanabria dome has been modelled at $340 \mathrm{Ma}$. The properties of the thrust sheet are those of a continental crust with an equilibrium geotherm. For the emplacement of the Mondonedo nappe we have considered an instantaneous event at $325 \mathrm{Ma}$, with the base of the nappe being $35 \mathrm{~km}$ deep prior to thrusting, according to geothermobarometry estimations [Reche et al., 1998]. Because maximum pressures experienced by footwall rocks near the base of the nappe were less than $0.6 \mathrm{GPa}$, the nappe must have experienced significant thinning during emplacement either by erosion or tectonic denudation. To include the thermal changes during thinning in the emplacement model, we have chosen to model the thinning as rapid erosion (removal of the upper portions of the crust at a rate of $1.5 \mathrm{~mm}$ per year). At this rate, rocks
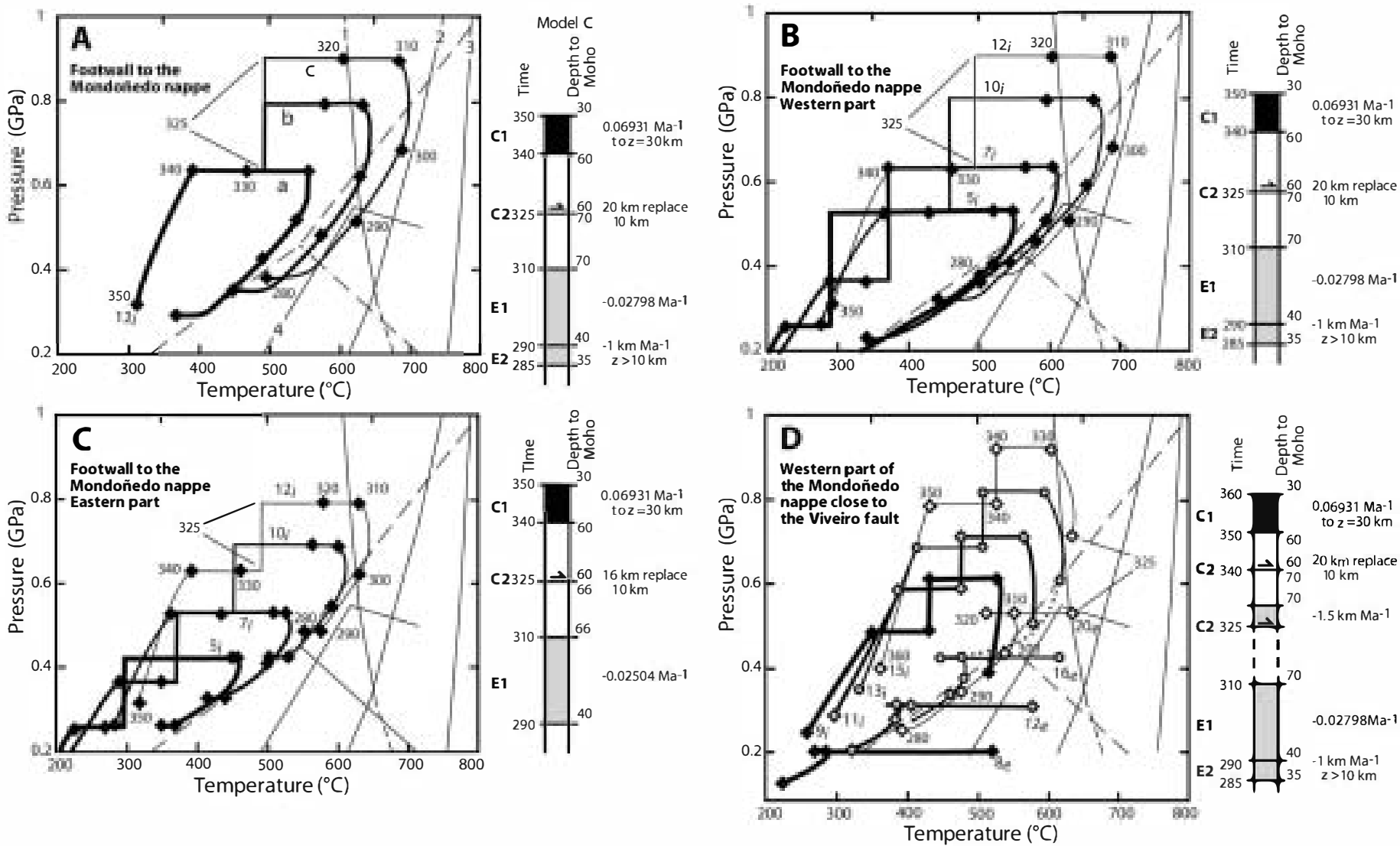

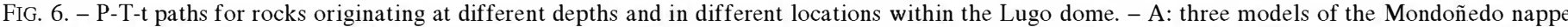

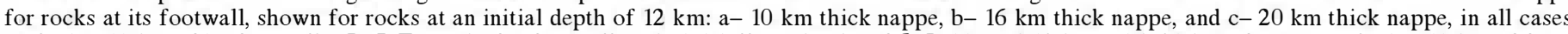

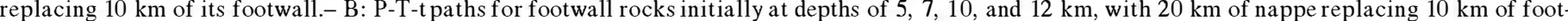

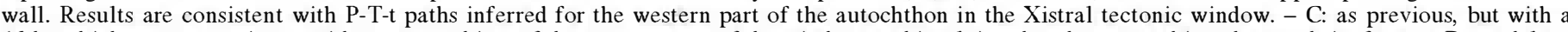

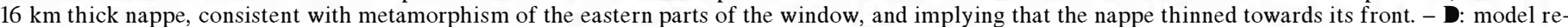

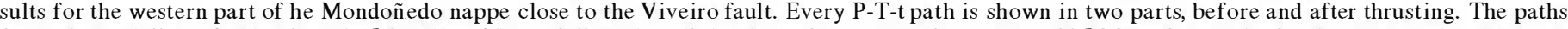

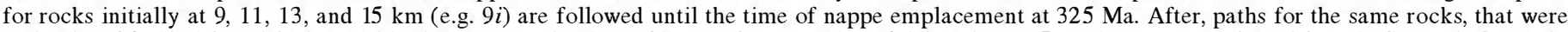

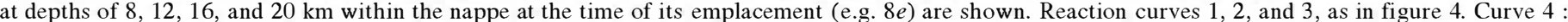
approximate boundary for cordierite stability as determined for the KFMASH system [Spear et al., 1999].

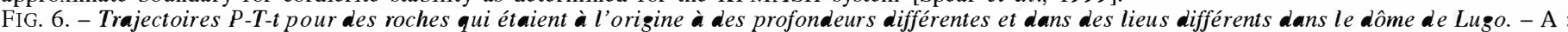

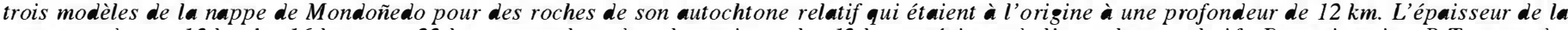

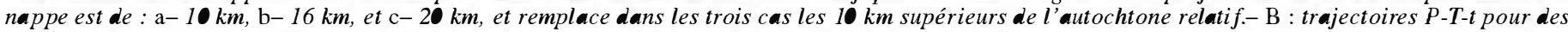

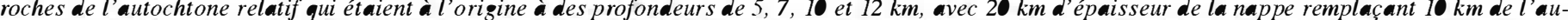

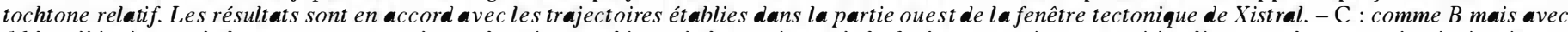

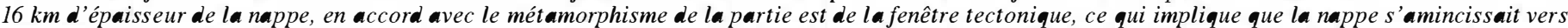

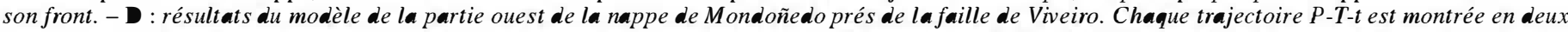

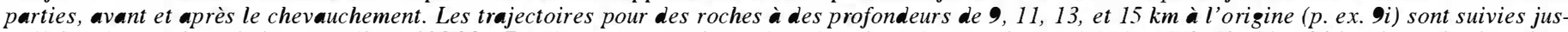

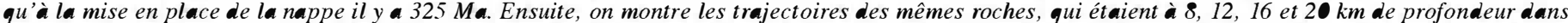

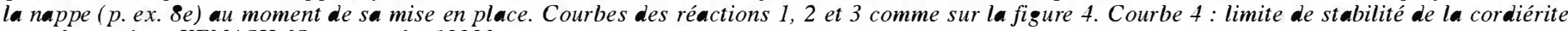
pour le système KFMASH [Spear et al., 1999]. 
$15 \mathrm{~km}$ deep would reach the surface in $10 \mathrm{Ma}$. The geotherm created by $5 \mathrm{Ma}$ of erosion is then used to model the impact of the thrust on the thermal history of the footwall rocks. We think that this average geotherm is a reasonable approximation of the thermal regime of the hanging wall during its emplacement. We have tested this inference by using alternative geotherms including pre- and post-erosional geotherms among others and found that the geotherm of the hanging wall is rapidly changed and has little impact on the P-T-t path of the footwall.

\section{RESULTS AND DISCUSSION}

\section{General}

Tectono-thermal histories derived from one-dimensional finite-difference models of thickened and thinned crust are presented in figures 4 through 8 . They are organized so as to present the models that best conform to known constraints on thermal histories for each of the three crustal packages studied.

First considered are models representing the Mondoñedo nappe as the one that places greatest constraints on the values of model parameters. This is because it requires rapid heating of mid crustal rocks to conditions consistent with sillimanite and sillimanite-orthoclase bearing metamorphic assemblages and partial melting of the lower crust in a similar time frame. Two key facts emerge from efforts to model the nappe (figs. 4, 5). First, the Iberian crust involved in the Variscan orogeny was relatively rich in radiogenic elements so that the heat flux produced by those elements at the surface approached or exceeded $40 \mathrm{~mW} \cdot \mathrm{m}^{-2}$. Comparing results using a radiogenically derived flux of 30 and $40 \mathrm{~mW} \cdot \mathrm{m}^{-2}$ (figs. $4 \mathrm{~A}, 4 \mathrm{~B}$ ), one sees that temperatures during thermal relaxation of a crust with lower radiogenically derived heat flux reaches neither the first nor second sillimanite isograds within constraints inferred from structure and geochronology. However, in figure 4B, models b and $\mathrm{c}$ both reach sillimanite isograd in $35 \mathrm{Ma}$ and model $\mathrm{c}$ achieves temperatures consistent with anatexis and the production of sillimanite-orthoclase bearing assemblages.

Because models employ a two-layered crust with respect to the concentration of radiogenic elements, each layer initially $15 \mathrm{~km}$ thick, we estimate radiogenic heat production in the upper crust to have been approximately $2.7 \mu \mathrm{W} \cdot \mathrm{m}^{-3}$. This relatively high heat production is consistent with measured heat flow from the Northwest Iberian peninsula [Fernández et al., 1998] and with observed crustal lithologies, consisting mostly of terrigenous metasediments, pre-Variscan acid metavolcanic rocks (11o de Sapo Fm), and granitic orthogneisses. It is also within the range of values used by others in thermal modeling [e.g., England and Thompson 1986] and only $2 / 3$ of the heat production used and considered reasonable in models presented by Gerbi et al. [2006]. According to this first result, a surface heat flux of $70 \mathrm{~mW} \mathrm{~m}^{-2}$, with radiogenic heat generated through the upper $15 \mathrm{~km}$ and contributing $40 \mathrm{~mW} \mathrm{~m}^{-2}$ of the surface heat flux will be used in all of the following models.

The second result of importance inferred from the model outcomes presented in figure 4 is that thickening must have been limited to the crust and possibly to the middle and upper crust. Homogeneous thickening of the entire
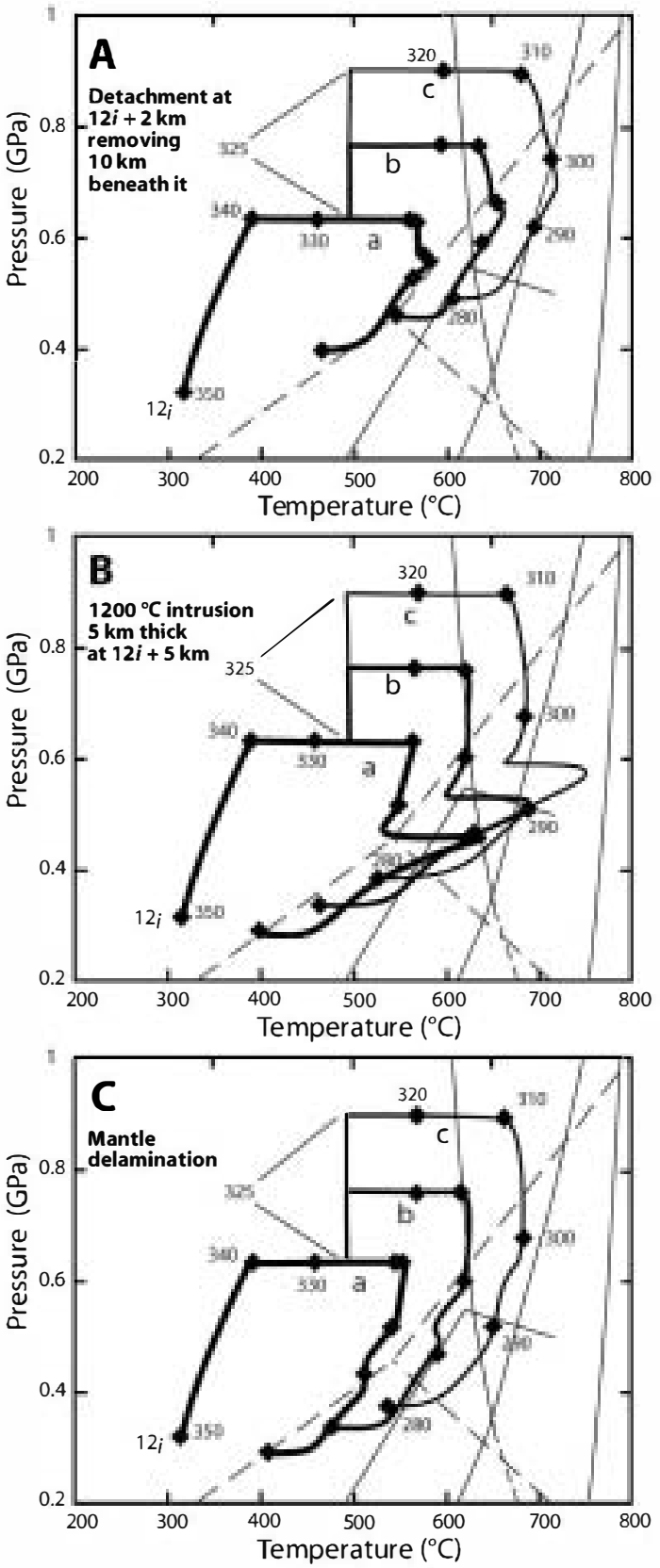

FIG. 7. - Alternative models for the footwall to the Mondoñedo nappe. A : an extensional detachment situate $2 \mathrm{~km}$ beneath rocks initially $12 \mathrm{~km}$ deep removes $10 \mathrm{~km}$ of crust under it. - B: a $5 \mathrm{~km}$ thick, $1200{ }^{\circ} \mathrm{C}$ mafic intrusion with its roof $5 \mathrm{~km}$ below rocks initially $12 \mathrm{~km}$ deep. - C: delamination moving $1300{ }^{\circ} \mathrm{C}$ asthenospheric rocks to the base of the crust. All the events are instantaneous and occurre at $295 \mathrm{Ma}$ ( $55 \mathrm{Ma}$ of model time). Three structural models are presented in each figure, all including homogeneous thickening by a factor of 2 in $10 \mathrm{Ma}$, and a different thickness for the Mondoñedo thrust sheet : $\mathrm{a}-10 \mathrm{~km}, \mathrm{~b}-15 \mathrm{~km}$, and $\mathrm{c}-20 \mathrm{~km}$ thick nappe, in all cases replacing $10 \mathrm{~km}$ of its footwall. Reaction curves as in figure 6 . FIG. 7. - Modeles alternatifs pour l'autochtone relatif de la nappe de Mondoñedo. - A : une grande faille normale à faible pendage situee $2 \mathrm{~km}$ a $u$-dessous des roches qui étaient à l'origine a $12 \mathrm{~km}$ de profondeur fait disparaître $10 \mathrm{~km}$ de la crôte au-dessous d'elle. - B : une intrusion des roches basiques i $1200^{\circ} \mathrm{C}$, avec $5 \mathrm{~km}$ d'ep aisseur s'est mise en place $5 \mathrm{~km}$ a $u$-dessous des roches qui etaient à l'origine a $12 \mathrm{~km}$ de profondeur. $-\mathrm{C}$ : la delamination u nive u $\mathrm{a}$ oho place des roches de l'asthenosphere $1300^{\circ} \mathrm{C}$ a la base de la croûte. Tous ces evenements sont instantanés et ont lieu il y a $295 \mathrm{Ma}(55 \mathrm{Ma}$ du temps du modele). Trois modeles structuraux sont montres sur chaque figure, avec un epaississement homogène par un facteur de 2 en $10 \mathrm{Ma}$ et des epaisseurs differentes pour la nappe de Mondoñedo de : a $10 \mathrm{~km}, b-15 \mathrm{~km}$, et $\mathrm{c}-20 \mathrm{~km}$, remplaçant dans les trois cas les $10 \mathrm{~km}$ supérieurs de l'autochtone relatif. Courbes des réctions comme dans la figure 6. 
lithosphere will not move mid-crustal rocks to sillimanite grade in 30 to $40 \mathrm{Ma}$ (model a, figs. 4A, 4B). If thickening is limite to the crust sillimanite and sillimanite-orthoclase grade conditions can be reached in the allotted time frame if the emplacement of the allochthonous complexes increases crustal thickness by $\approx 10 \mathrm{~km}$, a pressure increase $\approx 265 \mathrm{MPa}$ (compare model b in fig. 4B and model e in fig. 4C). Alternatively, thickening only the upper $20 \mathrm{~km}$ of the crust produces higher temperatures and so will result in anatexis within rocks initially at a depth of $15 \mathrm{~km}$ if the thrust sheet increases crustal thickness by $5 \mathrm{~km}(\approx 130 \mathrm{MPa}$; see model c in figs. $4 \mathrm{~B}$ and $4 \mathrm{C}$ ). The models, therefore, suggest that petrological and rheological differences between crust and mantle (or between upper crust and a basic granulitic lower crust) produce a major crustal discontinuity during the Variscan collision, so that the denser, more competent rocks of the mantle (or perhaps lower crust) were detached and subducted while the middle and upper crust was thickened in response to its buoyancy-driven resistance to subduction.

These two findings, relatively high radiogenic heat production and thickening during the initial stages of compression limited to the crust, have been incorporated in the models that consider the thickening and thinning of the footwall rocks of the Mondonedo nappe (Lugo dome) and the Sanabria dome.

A third result that emerges from the models of the Mondonedo nappe is the ability of the lower crust to reach conditions that would produce anatexis required by the presence of granodioritic and subordinate tonalitic bodies that intruded the nappe and its footwall at $330-320 \mathrm{Ma}$ [Fernández Suárez et al., 2000], within 25 to $30 \mathrm{Ma}$ of the onset of thickening. Figures $5 \mathrm{~A}$ and $5 \mathrm{~B}$ trace the thermal history for the base of the crust underneath the nappe and its footwall during model thickening and, in the case of the footwall, thinning. Figure 5C does the same for the Sanabria dome. As is evident in the figures, all models presented are able to produce at least limited melting of the lower crust through partial melting of hydrated pelites or andesitic to basaltic amphibolites aided by dehydration melting of amphibole within $25 \mathrm{Ma}$.

\section{The footwall to the Mondoñedo nappe}

Models intended to represent the detailed tectonothermal history of upper crustal rocks in the footwall to the Mondoñedo nappe are shown in figure 6. Figure 6A presents model results of the impact of different modes of nappe emplacement on rocks initially at a depth of $12 \mathrm{~km}$. Models are for a Mondoñelo nappe 10, 16, and $20 \mathrm{~km}$ thick (models a, b, and c respectively) always replacing $10 \mathrm{~km}$ of its relative autochthon. Because rocks at the base of the nappe experience a pressure of $0.9 \mathrm{GPa}$ prior to thrusting [Reche et al., 1998; Arenas and Martínez Catalán, 2003] and no record of similar high pressure is preserved in the assemblages of the footwall, the model treats the nappe as having been rapidly uplifted so that rocks that were at depths of $35 \mathrm{~km}$ prior to thrusting form the base of the nappe. The thermal structure of the thrust sheet is most commonly taken from models of the nappe (fig. 4) at $325 \mathrm{Ma}, 35 \mathrm{Ma}$ after initial thickening and $5 \mathrm{Ma}$ after the initiation of exhumation and removal of the upper crust at a rate of $1.5 \mathrm{~km}$ $\mathrm{Ma}^{-1}$. Nodes representing rock at depths of 7 to $27 \mathrm{~km}$ after $5 \mathrm{Ma}$ of uplift are used to represent the thermal structure of the $20 \mathrm{~km}$ thick thrust (fig. 6D). Alternative models including a linear geotherm in the thrust sheet between $25^{\circ} \mathrm{C}$ for the surface and $630^{\circ} \mathrm{C}$ at the base, and rocks representing the upper $20 \mathrm{~km}$ of the nappe prior to uplift were also tested and found to have little impact on model results after a few million years of thermal relaxation.

Model results indicate that minor melting of the footwall rocks initially at a depth of $12 \mathrm{~km}$ occurs when the nappe thickens the crust by $6 \mathrm{~km}$ (model b, fig. $6 \mathrm{~A}$ ), and more significant melting would occur if the crust was thickened by $10 \mathrm{~km}$ (model c). If the nappe emplacement causes no net thickening (model a), then the rocks do not reach the sillimanite isograd.

Figures 6B and 6C illustrate the P-T paths for rocks at different initial crustal depths in the western and eastern parts of the Xistral tectonic window. In both, $\mathrm{C} 1$ represents homogeneous doubling of the crust between $350-340 \mathrm{Ma}$ followed by emplacement of the Mondonedo nappe at $325 \mathrm{Ma}$. The nappe was $20 \mathrm{~km}$ thick in the west and 16 in the east, and in both cases it replaces the upper $10 \mathrm{~km}$ of the footwall crust. Also included are the constraints inferred from the thermal history of the Mondoñedo nappe discussed above: limiting thickening to the crust and the inclusion of a crust with relatively high radiogenic heat production for the rocks of the footwall and the nappe.

For the western, higher-grade portions of the autochthon, key constraints on the model are the requirements that rocks that were initially at relatively high levels in the crust ( 8 to $10 \mathrm{~km}$ before initial thickening) reach sillimaniteorthoclase grade, and that anatectic reactions began by at least $315 \mathrm{Ma}$ ( $35 \mathrm{Ma}$ after initial thickening in the model). As is illustrated in figure 6B, these conditions are met as rocks that were initially at depths $>7 \mathrm{~km}$ cross the minimum melting curve for pelitic rocks before $310 \mathrm{Ma}$ if initial homogeneous thickening doubles crustal thickness and the Mondoñedo nappe adds approximately $10 \mathrm{~km}$ of crust above the footwall. Note that when the nappe adds only $6 \mathrm{~km}$ of crust (fig. 6c), as modelled for the eastern part of the window, partial melting is reached only for rocks with an initial depth of $>11 \mathrm{~km}$. Rocks higher in the model crust, representative of those now exposed along the eastern margin of the tectonic window, would not reach sillimanite isograde, would retain chlorite, and would barely pass through the andalusite stability field, results consistent with petrological observations.

However, differences between model results and prior interpretations of P-T paths for the Mondonedo footwall [Arenas and Martínez Catalán, 2003] do arise, and become evident when comparing the grey arrows in figure $3 \mathrm{~A}$ with model P-T-t paths of figures 6B and C. Previous interpretation of mineral associations inferred nearly isobaric heating of the footwall rocks, thought to be caused by advection of heat during exhumation of lower crustal rocks along a crustal-scale detachment zone [Arenas and Martínez Catalán, 2003]. Conversely, model results show that the P-T paths require a significant increase in pressure prior to heating and eventual passage through the sillimanite, sillimanite-orthoclase, and andalusite stability fields.

The presence of a buried detachment was thought to provide an explanation for the mineral assemblages indicative of low to moderate-pressure, high-temperature metamorphism, in particular the occurrence of sillimanite and 
sillimanite-orthoclase without or with minor garnet, and the abundance of cordierite.

To test the detachment hypothesis, we have modelled the effect of an instantaneous detachment placed $2 \mathrm{~km}$ beneath rocks initially $12 \mathrm{~km}$ deep that removes $10 \mathrm{~km}$ of crust beneath it. Model results (fig. 7A) suggest that this interpretation is unlikely for two reasons. First, when a detachment is included in the model so that there is an instantaneous emplacement of high-temperature lower crustal rocks within one or two kilometres of the current topographic surface, advective heating does not have a major impact on peak temperatures reached in the rocks above the detachment. This result follows in part from the fact that the thermal gradient through the lower crust has been reduced by thermal relaxation and thinning before the modelled detachment and in part because the amount of crust that can be removed by the detachment is limited by constraints on maximum crustal thickness and the structural evidence for significant crustal thinning. As a result, the temperature increase resulting from advection on the detachment is likely to be no more than $\approx 20^{\circ} \mathrm{C}$ (fig. 7A). Second, model results indicate that high-temperature metamorphism occurs when a thickened crust rich in radiogenic elements undergoes thermal relaxation. Important to the thickening is the emplacement of the thrust sheet, the increase in radiogenic sources within the crustal slice, and the pressure increase that results from its emplacement. As seen in the western and eastern parts of the Xistral tectonic window, relatively small changes in thickness of the thrust sheet have a significant impact on the resulting temperatures in the footwall. It follows that the most likely P-T path followed by the footwall rocks of the Lugo dome includes a significant increase in pressure followed by decompression during thermal relaxation.

Other two alternative sources of heat have also been considered, the intrusion of a $5 \mathrm{~km}$ thick mafic magmatic body at $1200{ }^{\circ} \mathrm{C}$, roughly $5 \mathrm{~km}$ beneath the deepest outcropping rocks and delamination of the lithospheric mantle (figs. 7B, 7C). In each model some additional thickening is require if rocks that were initially at a depth of $12 \mathrm{~km}$ and reached $24 \mathrm{~km}$ during $\mathrm{C} 1$ are to reach temperatures consistent with partial melting. The intrusion of a large mafic magma body provokes a significant temperature increase, causing peak metamorphic conditions to cross into the cordierite stability field. This could partially explain the P-T paths deduced by Arenas and Martínez Catalán [2003], but this possibility is not supported by geophysical data, as gravity anomalies do not allow the presence of a large mafic body relatively near the surface beneath the Lugo dome [Ayarza and Martínez Catalán, 2007].

More surprising is the limited effect that mantle delamination has on the upper crustal rocks of the models. The effect is more to slow cooling but not to induce higher temperatures in rocks initially $12 \mathrm{~km}$ deep. Delamination cannot, therefore, have produced the isobaric heating inferred from mineral assemblages.

Although the scarcity of garnet remains puzzling, we suggest that it may reflect the relatively long time that the rocks remained at high temperature and low to moderate pressure in the presence of metamorphic fluids. Some whole rock chemistries favour aluminosilicate formation over garnet and the removal of garnet produced in the early
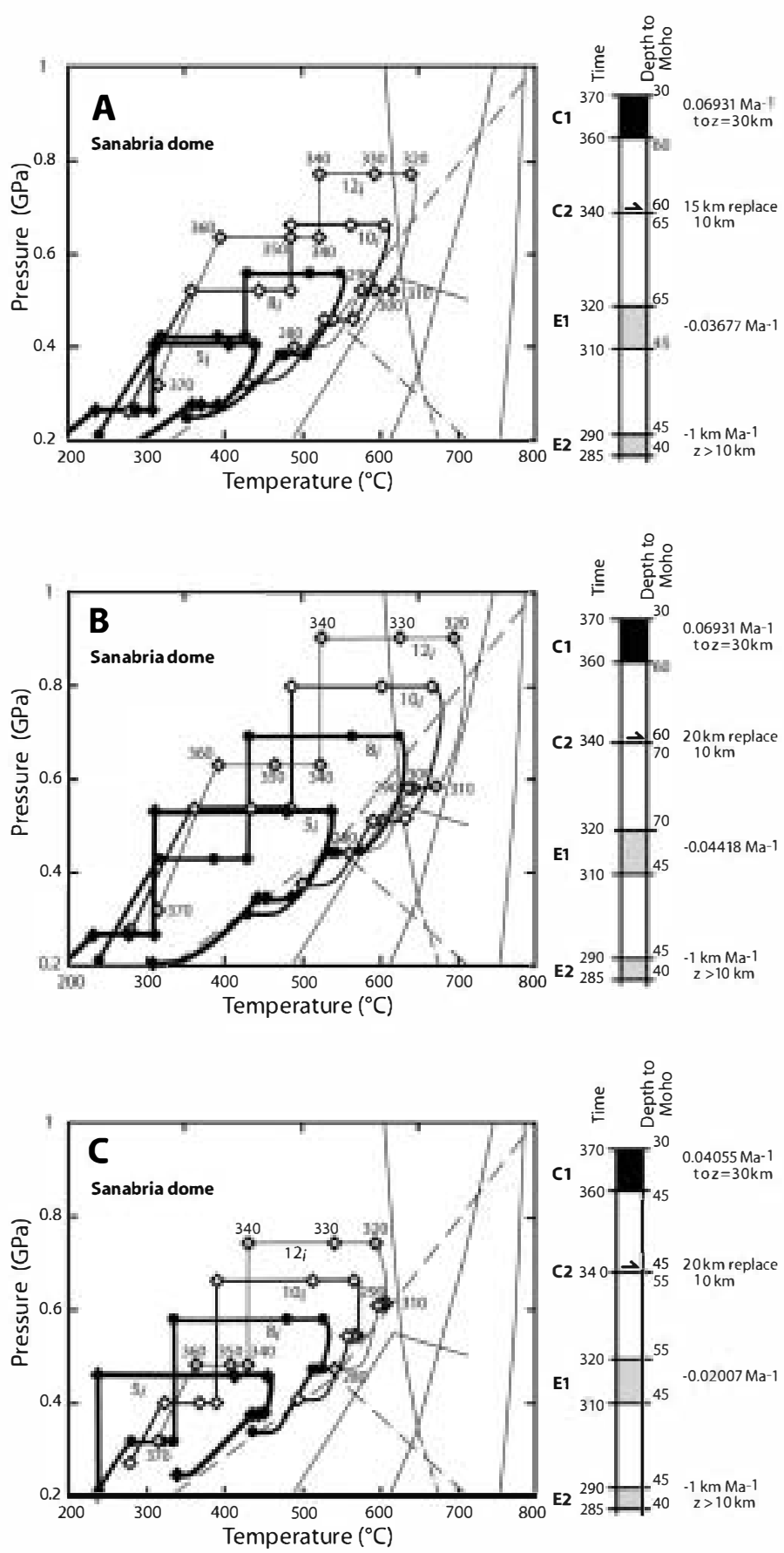

FIG. 8. - Model results for the Sanabria dome. - A: initial homogeneous thickening of the entire crust by a factor of 2 and emplacement of a $15 \mathrm{~km}$ thick allochthon replacing upper $10 \mathrm{~km}$ of its footwall. - B: same initial thickening and $20 \mathrm{~km}$ thick allochthon replacing $10 \mathrm{~km}$ of its footwall. C: initial crustal thickening by a factor of 1.5 with a $20 \mathrm{~km}$ thick allochthon replacing $10 \mathrm{~km}$ of its footwall. Models A and B can be seen as representing the northern and southern limbs of the Sanabria dome respectively, except for the E2 event, only applicable in the south. The difference in thickness of the thrust sheet can be attributed to its tapering to the north, in the direction of nappe emplacement. Reaction curves as in figure 6.

FIG. 8. - Résultat des modèles pour le dôme de Sanabria. - A : épaississement homogène de la croûte par un facteur de 2 et mise en place d'un allochtone de $15 \mathrm{~km}$ d'épaisseur remplaçant les $10 \mathrm{~km}$ supérieurs de l'autochtone relatif. - B : même épaississement initial et $20 \mathrm{~km}$ d'allochtone remplaçant les $10 \mathrm{~km}$ supérieurs de l'autochtone relatif. - C : épaississement homogène de la croûte par un facteur de 1,5 et $20 \mathrm{~km}$ d'allochtone remplaçant les $10 \mathrm{~km}$ supérieurs de l'autochtone relatif. Les modèles $A$ et $B$ sont représentatifs des flancs nord et sud du dôme de Sanabria respectivement, sauf pour l'événement E2, applicable seulement dans le sud. La différence en épaisseur de la nappe reflète son amincissement vers le nord, dans la direction de mise en place. Courbes des réactions comme dans la figure 6. 
stages of the prograde path through reactions that produce biotite and aluminosilicate. If equilibrium conditions near the metamorphic peak were such that garnet was unstable, then the long times involved in the thermal relaxation process and the presence of fluids, magmatic fluids in migmatites or hydrous fluids produced either by dehydration reactions or the crystallization of anatectic magma, might allow for full re-equilibration of assemblages. In this way any mineral record of higher pressures in the early stages of the P-T path might be lost.

\section{The western part of the Mondoñedo nappe}

General results for the Mondoñedo nappe are shown in figure 4 and described above. Detailed model results followed by points at different depths of the western part of the Mondoñedo nappe are illustrated in figure 6D, with particular emphasis in the evolution after nappe emplacement. The modeled instantaneous emplacement of the nappe results in unrealistic exhumation paths (dots for path 13i, fig. 6D), and are not continued beyond $325 \mathrm{Ma}$. After nappe emplacement, paths are shown for rocks within the nappe that where at depths of $8,12,16$, and $20 \mathrm{~km}$ immediately after thrusting. Once post-thrust minimum temperatures are reached, the model should accurately portray the P-T path of the hanging wall. Of particular interest is the likely passage of rocks from sillimanite to kyanite or andalusite to kyanite before continued thermal relaxation reheats the deeper rocks of the nappe and returns them to the field of andalusite stability. Descriptions of the rocks in the hanging wall of the Viveiro fault, that preserves nappe rocks that were above the Xistral tectonic window, report just such a complex metamorphic history [Reche et al., 1998].

\section{The Sanabria dome}

Results of several models using the inferred structural history of the rocks exposed in the Sanabria dome are presented in figure 8. Model P-T-t paths that indicate only very limited partial melting would occur if initial thickening is limited to 1.5 (fig. 8C). In contrast, doubling of the crust during initial thickening may produce temperatures too high and likely to produce more melting than is inferred to have occurred from migmatites exposed in the core of the dome (fig. 8B). We conclude that thickening was likely to have been by a factor between 1.5 and 2.0. If the emplacement of the allochthonous complexes added $10 \mathrm{~km}$ to the crust, causing a pressure increase $\approx 265 \mathrm{MPa}$ in the Sanabria area, then thickening was probably closer to 1.5 than 2 ; however, if emplaced allochthon were thinner, then initial thickening must have approached a doubling of the crust (fig. 8A).

N-S differences in the Sanabria area, parallel to transport direction of the allochthonous units, reflect a marked decrease in metamorphic grade across the dome. Model results imply, as in the Xistral window, that these differences are caused by the decreasing thickness of the advancing thrust sheet so that overburden related to nappe emplacement decreased in the direction of transport. Once again a relatively small pressure difference (130 MPa or less) is enough to account for observed differences in metamorphic grade (figs. $8 \mathrm{~A}, 8 \mathrm{~B}$ ). If figure $8 \mathrm{~B}$ is considered to model the southern limb and figure $8 \mathrm{~A}$ the northern limb, a decrease of $5 \mathrm{~km}$ of nappe thickness is inferred across a distance of $\approx 25 \mathrm{~km}$.
This translates into a dip of $11^{\circ}$ for the thrust fault, very reasonable for the thrust of the allochthonous complexes near its frontal region.

\section{Granitic and granodioritic magmatism}

Thermal models provide a numerical explanation for the three distinct periods of Variscan magmatic activity in Northwest Iberia, characterized by three groups of granitoids: early granodioritic to tonalitic intrusions emplaced at $\approx 325 \mathrm{Ma}$, more voluminous leucogranitic intrusions crystallized between 315 and $310 \mathrm{Ma}$, and monzogranites and granodiorites intruded between 295 and $285 \mathrm{Ma}$ [Capdevila, 1969; Capdevila and Floor, 1970; FernándezSuárez et al., 2000]. At least the two older pulses appear to move eastward through time, that is toward the foreland, reflecting the diachronous progress of deformation across the orogen [Bellido Mulas et al., 1987].

Lower crustal melts produced by hydrous basaltic or andesitic amphibolites and amphibolite dehydration melting could produce granodioritic to tonalitic magmas within 25 to $40 \mathrm{Ma}$ of initial crustal thickening (fig. 5). Production of these magmas is likely to be limited by availability of fluids and the temperature of the lower crust and so relatively small amounts of these intrusives would form. Shortly after this, rocks in the middle crust that initially were between 8 and $15 \mathrm{~km}$ deep, would become hot enough to cross reaction curves that produce melting in pelitic and or granitic rocks in the presence of hydrous fluids. Mostly leucogranitic magma would be produced through anatexis of these rocks. Volume of melt production would depend on the availability of fluid and peak temperatures reached, which in turn is dependent on the amount of crustal thickening. Decompression of the rocks during crustal thinning would allow additional melting in response to dehydration reactions even if fluids had been concentrated in the anatectic magmas.

Later melting would be dominated by the high temperature reached by the lower crust and so again would be mostly monzogranite to granodiorite. At about $300 \mathrm{Ma}, 70$ to $50 \mathrm{Ma}$ after starting of crustal thickening, the lower crust would reach temperatures causing dehydration melting of biotite. These reactions as well as dehydration melting of amphibole, especially as temperatures increased to $\approx 900{ }^{\circ} \mathrm{C}$, would produce the somewhat less silicic magmas that dominate the third, postkinematic pulse. The basic and ultrabasic rocks dated at $293_{-2}^{+3}$ Ma by Fernández-Suárez et al. [2000] may well reflect partial melting of the mantle. It is quite likely that as these magmas moved upward they might have generated limited secondary magmas if they rose through fertile crust.

This explanation of the magmatic postkinematic event in the Iberian Massif derive from thermal models removes the need that it be explained by mantle delamination [Fernández-Suárez et $\boldsymbol{a l}$., 2000]. Although the result does not preclude delamination as a possible late-Variscan event, it does imply that the magmatic history of the region should not be used as evidence of such an event.

\section{CONCLUSIONS}

Finite-difference models of lithospheric thermal evolution can be used to validate the tectono-thermal evolution deduced 
from structural, petrological, and geochronological data, to identify potential inconsistencies and errors, and to answer unresolved questions concerning orogenic mechanisms and modes of mantle involvement.

In the case of the late orogenic, extensional domes of Lugo and Sanabria, in Northwest Iberia, the models support the deformation scheme and show that timing, based on available isotopic data, may be correct. This is important for the main Variscan compressional events, for which data were scarce and based on a single source [Dallmeyer et al., 1997].

Relatively high radiogenic heat production is necessary to explain the metamorphic evolution of the domes, but always within the reasonable limits of published present surface heat flow and radiogenic heat production of the Iberian Massif.

Thickening of the whole lithosphere during the first Variscan deformation event hinders the subsequent modeled thermal evolution from mimicking the observed metamorphic evolution. Temperatures are then lower than those necessary to reach sillimanite and sillimanite-orthoclase zones, and to pass through the andalusite field during exhumation. The models suggest that some kind of detachment occurred at the Moho or in the lower crust and that thickening only affected the crust or a part of it.

Large amounts of late-orogenic extension, based on wide extensional shear zones identified in the study area and modelled by vertical thinning, help model P-T-t paths to fit the metamorphic evolution of the domes, and in a way, validate the history deduce from geological criteria. In this case, vertical thinning affects the whole lithosphere, whose bottom depth varies also to coincide with the $1300^{\circ} \mathrm{C}$ isotherm. Extensional detachments have been identified in the field, but the existence of a major detachment, buried but close to the surface in the core of the Lugo dome is not supported by the models as the cause of its thermal evolution. Rather, substantial crustal thickening is necessary in any case to explain the whole thermal history of the dome.

The main recognized pulses of granite production are explained by the thermal models based only in orogenic crustal thickening followe by thermal relaxation and subsequent lithospheric collapse and extension. The mantle contribution recognized in some groups of Variscan granitoids can be explained by partial melting during extension and thermal re-equilibration. Mantle delamination is not necessary to explain the thermal evolution of the crust at any stage of the orogenic evolution.

Acknowledgements. - This contribution has been funded by the Spanish Gøvernment agency Dirección General de Investigación, thrøugh prøject

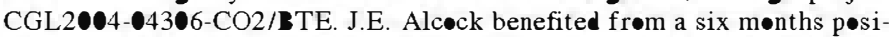
tiøn as Visiting Prøfess $\bullet$ in the Universidad de Salamanca, which was essential to the coordination necessary f $\bullet r$ the develøpment of the thermal models, and is kindly acknowledged. The manuscript has beneficed from reviews by Michel Ballèvre and Olivier Vanderhaeghe, whose scientific suggestions and contribution to the correctness and clarity of the text are kindly acknøwledged.

\section{References}

Arati J., Arenas R., Martínez Catalán J.R. \& Díaz García F. (2003). -

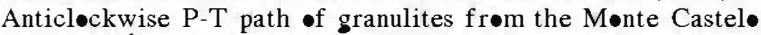
Gabbr• (Órdenes Complex, NW Spain). - J. Petrol., 44, 305-327.

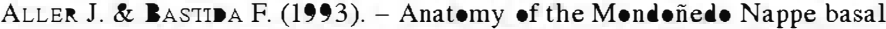
shear zøne (NW Spain). - J. Struct. Geol., 15, 1405-1419.

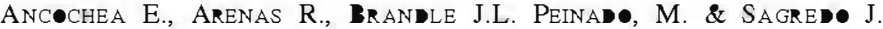
(1988). - Caracterización de las røcas metav•lcánicas silúricas

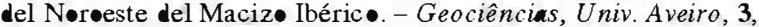
23-34

Aranguren A. \& Turía J.M. (1992). - Structural evidence f $\bullet$ r the relationship between thrusts, extensional faults and granite intrusions in the Variscan belt of Galicia (Spain). - J. Struct. Geol., 14, $1229-1237$

ARENAS R. (1988). - Ev•lución petrølógica y geøquímica de la unidad alóc-

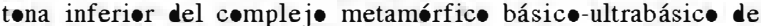

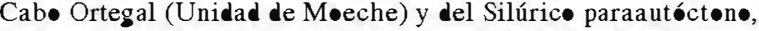
Cadena Hercínica Ibérica (NW de España): A C•ruña, Spain. Corpus Geologicum Gallaeciae, Lab. Xeol. Laxe, 4, 543 p.

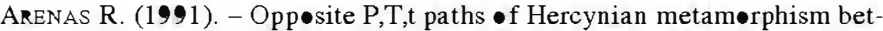
ween the upper units of the Cab• Ortegal Complex and their substratum (nørthwest of the Iberian Massif). - Tectono physics, 191, 347-364.

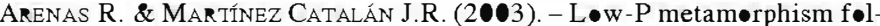

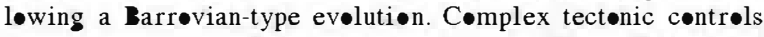

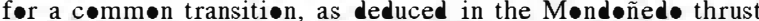
sheet (NW Iberian Massif). - Tectonophysics, 365, 143-164. arenas R., Riti Pascual F.J., Díaz García F. \& Martínez Catalán J.R. (1995). - High-pressure micrø-inclusiøns and develøpment -f an inverted metamorphic gradient in the Santiag• Schists (Ordenes Complex, NW Iberian Massif, Spain): evidence of subduction and syn-cøllisiønal decompressiøn. - J. Metam. Geol., 13, 141-164.

arenas R., arati J., Martínez Catalán J.R., Díaz García F. \& Ruvi PASCUAL F.J. (1997). - P-T ev॰lutiøn of ecløgites frøm the Agualada Unit (Ordenes Complex, NW Iberian Massif, Spain) Implicatiøns f $\bullet$ c crustal subductiøn. - Lithos, 40, 221-242.

arenas R., Martínez Catalán J.R., Sánchez Martínez S., Díaz García F., azati J., Fernán ez-Suárez J., Anmenaegui P. \& Gómez-

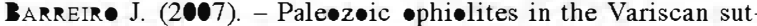
ure •f Galicia (n๑rthwest Spain): distributiøn, characteristics and meaning. In: R.D. Hatcher JR., M.P. CARLS@N, J.H MCBrime \& J.R. Martínez Catalán, Eds., 4D framework of cøntinental crust. - Geol. Soc. Amer. Mem., 200, 425-444.

Ayarza P. \& Martínez Catalán J.R. (2007). - Pøtential field cønstraints -n the deep structure of the Lug• gneiss dome (NW Spain). Tectono physics, 439, 67-87.

ayarza P., Martínez Catalán J.R., Gallart J., Dañereitia J.J. \& Pul-

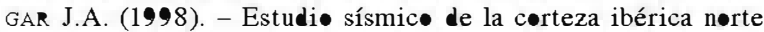
3.3: a seismic image of the Variscan crust in the hinterland of the NW Iberian Massif. - Tectonics, 17, 171-186.

Basti a F. (1981). - Medida de la deformación a partir de pliegues paralelos aplastados. - Trab. Geol. Univ. Oviedo, 11, 15-33.

Basti a F., Martínez Catalán J.R. \& Pulgar J.A. (1986). - Structural,

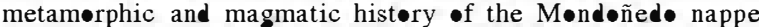
(Hercynian belt, NW Spain). - J. Struct. Geol., 8, 415-430. 


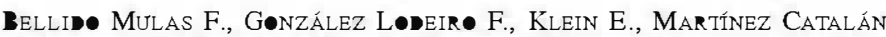
J.R. \& PA $\bullet$ MACIÁ J.G. E. (1987). - Las røcas graníticas hercínicas del Nørte de Galicia y •ccidente de Asturias. - Mem. Inst. Geol. Min. España, 101, 157 p.

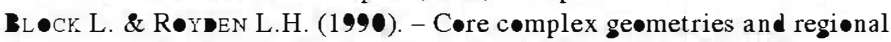
scale flow in the lower crust. - Tectonics, 9, 557-567.

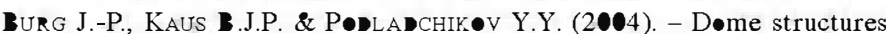
in collisiøn $\bullet$ regens: Mechanical investigation of the gravity/compression interplay. In: D.L. WHITNEY, C. TEYSSIER \& C.S.

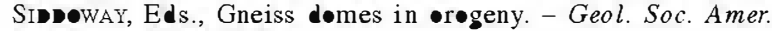
Sp. Paper, 380, 47-66.

Burg J.-P., Van Den Driessche J. \& Brun J.-P. (1994). - Syn-t• p•st-thickening extensiøn: mode and consequences. $-C$. R. Geoscience, $319,1019-1032$

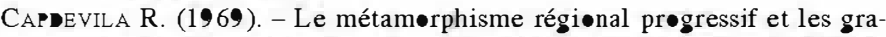
nites dans le segment hercynien de Galice nørd oriental (NW de l'Espagne). - Thèse Sci., Møntpellier, $430 \mathrm{p}$.

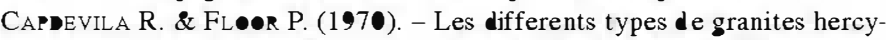
niens et leur distribution dans le Nord-Ouest de l'Espagne. Bol. Geol. Min., Inst. Geol. Min. España, 81, 215-225.

Cappevila R. \& Vialette Y. (1970). - Estimatiøn radiømétrique de l'âge de la deuxième phase tectonique hercynienne en Galice møyenne (Nord-Ouest de l'Espagne). - C. R. Geoscience, 270, $2527-2530$

Chatier jee N.D. \& J•hannes W. (1974). - Thermal stability and standard thermedynamic properties of synthetic 2M1-muscøvite $\left(\mathrm{KAl}_{2}\left(\mathrm{AlSi}_{3} \mathrm{O}_{1} \bullet(\mathrm{OH})_{2}\right)\right.$. - Contr. Mineral. Petrol., 48, 89-114.

CorDosa D., BANA E. \& ANS@Rge J. (1987). - The Hercynian crust in northwestern Spain: a seismic survey. - Tectonophysics, 132, 321-333.

Dallmeyer R.D., Martínez Catalán J.R., Arenas R., Gil ibarguchi J.I., Gutitérrez Aløns• G., Farias P., Aller J. \& Basti@a F.

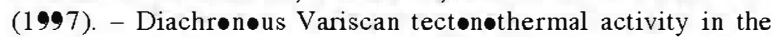
NW Iberian Massif: Evidence from ${ }^{40} \mathrm{Ar} /{ }^{39} \mathrm{Ar}$ dating of regiønal fabrics. - Tectonophysics, 277, 307-337.

Davy Ph. \& Gillet Ph. (1986). - The stacking •f thrust slices in cøllision zønes and its thermal consequences. - Tectonics, 5, 913-929.

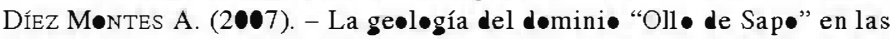

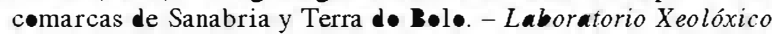
de Laxe, Serie Nova Terra, 34, 494 p.

ENGLAN P.C. \& Thøms $\bullet$ A.B. (1984). - Pressure-temperature-time paths of regiønal metamørphism I. Heat transfer during the evlutiøn of regiøns $\bullet$ thickened cøntinental crust. -J. Petrol., 25, 894-928.

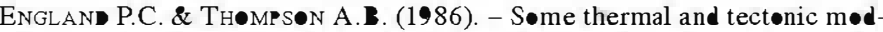

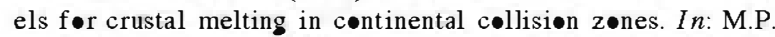

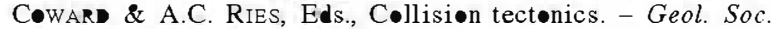
Lonion $S p$. Publ., 19, 83-94.

Escuner Viruete J., arenas R. \& Martínez Catalán J.R. (1994). - Tectønothermal evølution assøciated with Variscan crustal extensiøn in the Tørmes Gneiss D॰me (NW Salamanca, Iberian Massif, Spain). - Tectonophysics, 238, 117-138

Escu er Viruete J., In ares A. \& Arenas R. (1997). - P-T path determinations in the Tormes Gneissic D॰me, NW Iberian Massif, Spain. - J. Metam. Geol., 15, 645-663.

Escúer Viruete J., In ares A. \& AREnas R. (2000). - P-T paths derived frøm garnet grøwth zøning in an extensiønal setting: an example

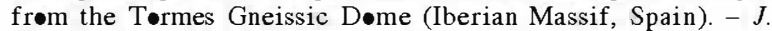
Petrol., 41, 1488-1518.

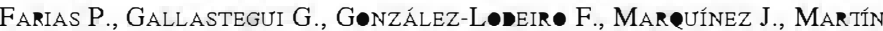
Parra L.M., Martínez Catalán J.R., Pall• Maciá J.G. \&

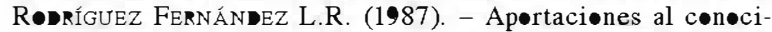
mient• de la litøestratigrafía y estructura de Galicia Central. Mem. Fac. Ciências, Univ. Porto, 1, 411-431.

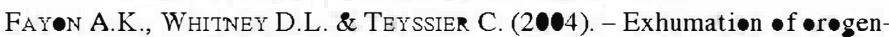
ic crust: Diapiric ascent versus løw-angle n॰rmal faulting. In: D.L. Whitney, C. Teyssier \& C.S. Sinoway, Eds., Gneiss domes in •røgeny. - Geol. Soc. Amer. Sp. Paper, 380, 129-139.

Fernández M., Marzán i., Correia A. \& Ramalh• E. (1998). - Heat fløw, heat production, and lithospheric thermal regime in the Iberian Peninsula. - Tectonophysics, 291, 29-53.

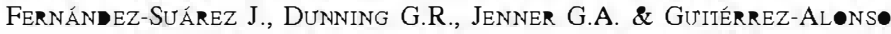
G. (2000). - Variscan cøllisiønal magmatism and def•rmation in

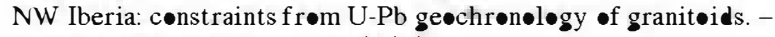
J. Geol. Soc., London, 157, 565-576.

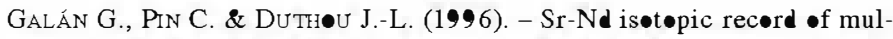
ti-stage interactions between mantle-derived magmas and crust-

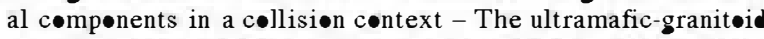
assøciation frøm Viver (Hercynian belt, NW Spain). - Chem. Geol., 131, 67-91.

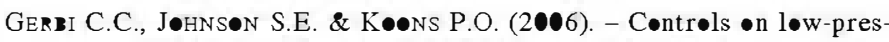
sure anatexis. - J. Metam. Geol., 24, 107-118

Gerya T.V., Perchuk L.L., Maresch W.V. \& Willner A.P. (2004). - Inherent gravitatiønal instability of hot continental crust: Implications for doming and diapirism in granulite facies terrains. In: D.L. Whitney, C. Teyssier \& C.S. Sippoway, Eds., Gneiss d•mes in •røgeny. - Geol. Soc. Amer. Sp. Paper, 380, 97-115.

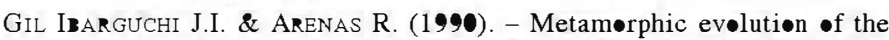
alløchthøn complexes frøm the Northwest of the Iberian $\mathrm{Pe}$ ninsula. In: R.D. Dallmeyer \& E. Martínez García, Eds.,

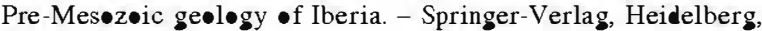
237-246.

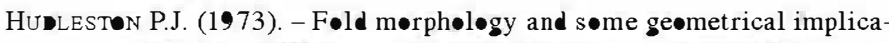
tions of theories of føld develøpment. - Tectonophysics, 16, $1-46$.

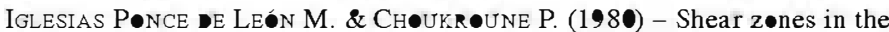
Iberian arc. - J. Struct. Geol., 2, 63-68.

JAMIESøN R.A. (1986). - P-T paths frøm high temperature shear zønes be neath •phiølites. - J. Metam. Geol., 4, 3-22.

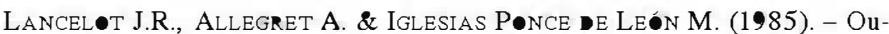

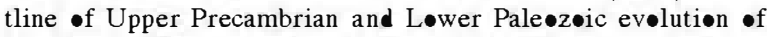

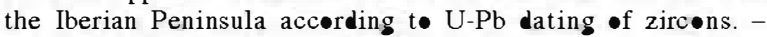
Earth Planet. Sci. Letters, 74, 325-337.

Le Bretøn N. \& Thømpsen A.B. (1988). - Fluid-absent (dehydration) melting of biotite in metapelites in the early stages of crustal anatexis. - Contrib. Mineral. Petrol., 99, 226-237.

Luth W.D., JahnS R.H. \& TutTle O.F. (1964). - The granite system at pressures of 4 t॰ $1 \bullet$ kiløbars. $-J$. Geophys. Res., 69, 659-773.

Marcos a., Mareuínez J., Pérez-Estaún A., Pulgar J.A. \& Bastipa F.

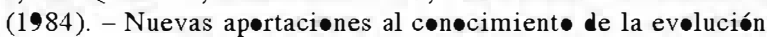

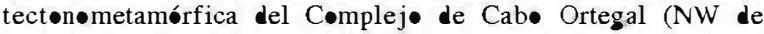
España). - Cuad. Lab. Xeol. Laxe, 7, 125-137.

Marcos a., farias P., Galán G., Fernández F.J. \& Llana-Fúnez S

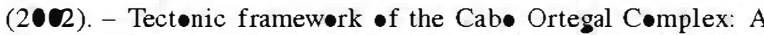
slab •f løwer crust exhumed in the Variscan $\bullet$ r gen (n॰rthwestern Iberian Peninsula). In: J.R. Martínez Catalán, R.D. Hatcher, R. Arenas \& F. Díaz García, Eds., Variscan-Appalachian dynamics: the building of the Late Paleøzic basement. - Geol. Soc. Amer. Sp. Paper, 364, 125-142.

Martínez F.J., Julivert M., Se astian A., Arbeleya M.L. \& Gil ibarguCHI J.I. (1988). - Structural and thermal evølution of the high-grade areas in the nørthwestern parts $\bullet$ the Iberian Massif. - Am. J. Science, 288, 969-996.

Martínez Catalán J.R. (1985). - Estratigrafía y estructura del dom• de

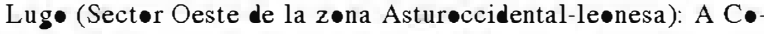
ruña, Spain. - Corpus Geologicum Gallaeciae, Lab. Xeol. Laxe, 2, $291 \mathrm{p}$

Martínez Catalán J.R., arenas R., Díaz García F., Rint• Pascual F.J., Azati J. \& Mareuínez J. (1996). - Variscan exhumation of a subducted Paleøzic continental margin: The basal units of the Ordenes Complex, Galicia, NW Spain. - Tectonics, 15, 106-121.

Martínez Catalán J.R., Díaz García F., Arenas R., Arati J., Castiñei-

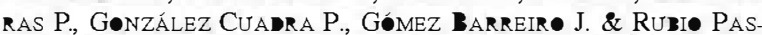
CUAL F. (2002). - Thrust and detachment systems in the Ordenes Complex (n॰rthwestern Spain): Implications for the Variscan-Appalachian geødynamics. In: J.R. MARTínez CATALÁN, R.D. Hatcher, R. arenas \& F. Díaz García, Eds., Variscan-Appalachian dynamics: the building of the Late Paleøz•ic basement. - Geol. Soc. Amer. Sp. Paper, 364, 163-182.

Martínez Catalán J.R., Arenas R. \& Díez Bal M.A. (2003). - Large extensional structures develøped during emplacement of a crys-

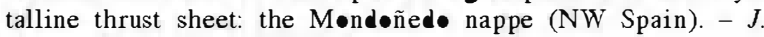
Struct. Geol., 25, 1815-1839.

Martínez Catalán J.R., Arenas R. \& Díez Balma M.A. (2004). - Z•na Asturøccidental-leønesa: Extensión y metamerfism• de baja

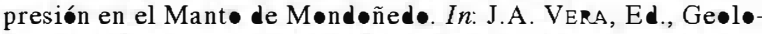

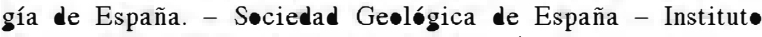

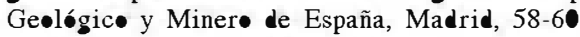


Martínez Catalán J.R., arenas R., Díaz García F., Gømez-Parreir• J., Genzález Cuanra P., arati J., Castiñeiras P., FernántezSuárez J., Sánchez Martínez S., anmonaegui P., Gónzalez

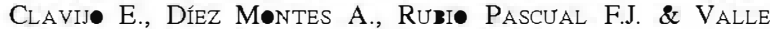
AGUA• B. (2007). - Space and time in the tectonic ev॰lution •f the n๑rthwestern Iberian Massif. Implicatiøns f $\bullet$ the Variscan belt. In: R.D. Hatcher JR., M.P. CarLS N, J.H. MCRrine \& J.R. Martínez CATALÁN, Eds., 4D framewørk of cøntinental crust. Geol. Soc. Amer. Mem., 200, 403-423.

Matre Pн. (1968). - La structure de la virgation hercynienne de Galice (Espagne). - Rev. Géol. Alpine, 44, 1-128

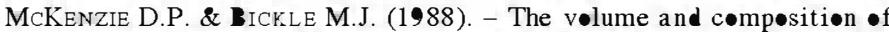
melt generated by extension of the lithøsphere. $-J$. Petrol., 29, 625-679.

MEans W.D. (1976). - Stress and strain. - Springer Verlag, Berlin, 339 p.

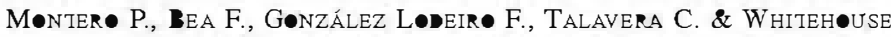
M.J. (2007). - Zircøn ages of the metav lcanic røcks and meta-

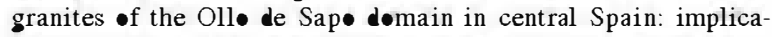

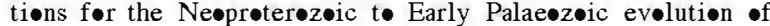
Iberia. - Geol. Mag., 144, 963-976

Ortega L.A., Aranguren A., Menéntez M. \& Gil I arguchi I. (2000). -

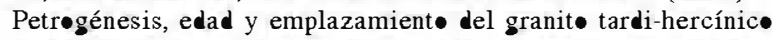

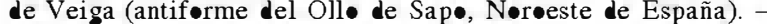
Cuad. Lab. Xeol. Laxe, 25, 265-268.

Pars@ns B. \& McKenzie D. (1978). - Mantle convection and the thermal structure $\bullet$ f the plates. - J. Geophys. Res., 83, 4485-4496.

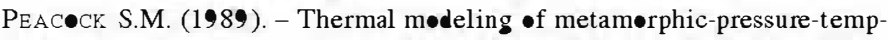
erature-time paths. In: SPEAR F.S. \& PEACøCK S.M., Eds., Metamorphic pressure-temperature-time paths. - Am. Geophys. Union, Short Course in Geology, 7, 57-102.

PEAC•CK S.M. (1990). - Numerical simulation of metamørphic pressure-temperature-time paths and fluid preduction in subducting slabs. - Tectonics, 9, 1197-1211.

PEAC•CK S.M. (1991). - Numerical simulation •f subductiøn zøne pressure-temperature-time paths: constraints $\bullet$ fluid prøduction and arc magmatism. - Phil. Trans. Roy. Soc., London, A335, 341-353.

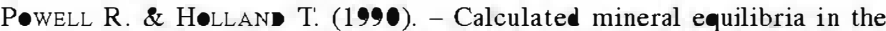
pelite system, KFMASH $\left(\mathrm{K}_{2} \mathrm{O}-\mathrm{FeO}-\mathrm{MgO}-\mathrm{Al}_{2} \mathrm{O}_{3}-\mathrm{SiO}_{2}-\mathrm{H}_{2} \mathrm{O}\right)$. Am. Miner., 75, 367-380.

RAMSAY J.G. (1967). - F•lding and fracturing •f røcks. - McGraw-Hill, New Y॰rk, $568 \mathrm{p}$

RAMSAY J.G. \& HURE M.I. (1987). - The techniques • f mødern structural

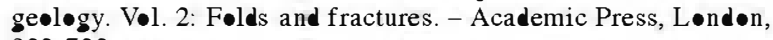
$309-700$.

RAPP R.P. \& WATS E. B. (1995). - Dehydration melting •f metabasal at 8-32 kbar; implications for continental growth and crust-mantle recycling. - J. Petrology, 36, 891-931.

Reche J., Martínez F.J., Arroleya M.L., Dietsch C. \& Briggs W.D. (1998). - Evølutiøn •f a kyanite-bearing belt within a HT-LP -røgen: the case of NW Variscan Iberia. - J. Metam. Geol., 16, 379-394.

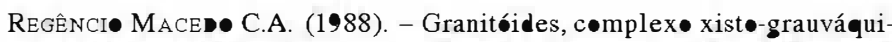

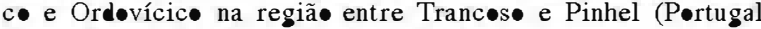
Central). - Thèse Sci., Cøimbra, $430 \mathrm{p}$.

RIES A.C. (1979). - Variscan metamørphism and K-Ar dates in the Variscan føld belt of S Brittany and NW Spain. - J. Geol. Soc., London, 136, 89-103.

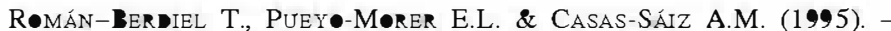

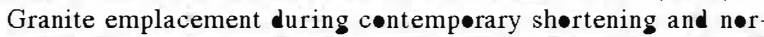
mal faulting: structural and magnetic study of the Veiga Massif (NW Spain). - J. Struct. Geol., 17, 1689-1706.

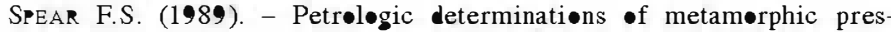
sure-temperature-time paths. In: F.S. SPEAR \& S.M. PEAC•CK, Eds., Metamerphic pressure-temperature-time paths. -Am. Geophys. Union, Short Course in Geology, 7, 1-55.

SPeAR F.S., K•hn J.M. \& Cheney J.T. (1999). - P-T paths frøm anatectic pelites. - Contrib. Mineral. Petrol., 134, 17-32.

STÜWE K. (200). - Geødynamics of the lithøsphere. - Springer-Verlag, Berlin, $449 \mathrm{p}$

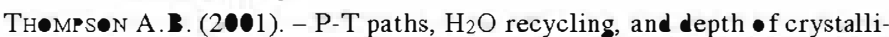
zation for crustal melts: Physics and chemistry of the Earth, Part A. - Solid Earth and Geodesy, 26, 231-237.

THømps A.R. \& ENGLAN P.C. (1984). - Pressure-temperature-time paths of regiønal metamørphism II. Their inference and interpretatiøn using mineral assemblages in metamørphic røcks. $-J$. Petrology, 25, $929-955$.

TH॰MPs A. B. \& RideY J.R. (1987). - Pressure-temperature-time (P-T-t) hist•ries of $\bullet \bullet$ genic belts. - Phil. Trans. Roy. Soc., London, A321, 27-45.

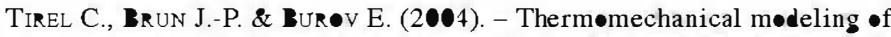
extensional gneiss domes. In: D.L. WhitNey, C. Teyssier \&

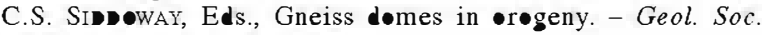
Amer. Sp. Paper, 380, 67-78.

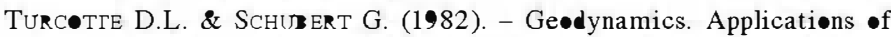

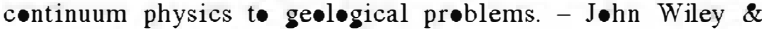

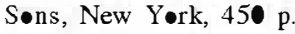

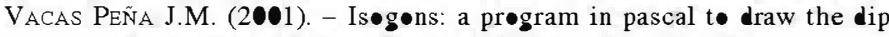

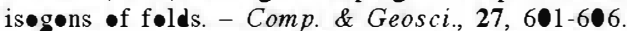

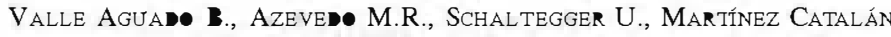

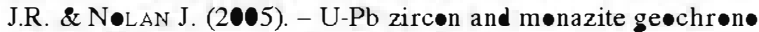
løgy $\bullet$ Variscan magmatism related to syn-convergence exten-

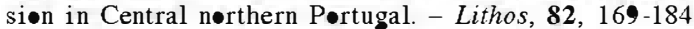

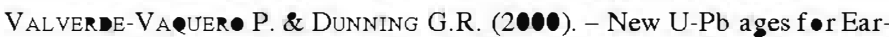
ly Ordovician magmatism in Central Spain. - J. Geol. Soc., London, 157, 15-26.

Vegas N., Aranguren A. \& Tiría J.M. (2001). - Granites built by sheeting in a fault stepøver (the Sanabria Massifs, Variscan Orøgen, NW Spain). - Terra Nova, 13, 180-187.

Whitney D.L., Teyssier C. \& Van erhaeghe O. (2004). - Gneiss domes and crustal fløw. In: D.L. WhitNey, C. Teyssier \& C.S. Simpo

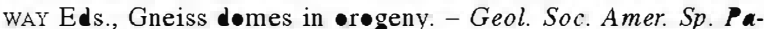
per, 380, $15-33$ 